\title{
ELECTROPHYSIOLOGICAL EFFECTS OF PEPTIDES DERIVED FROM PRO-OPIOMELANOCORTIN
}

\author{
I. J. A. URBAN \\ Rudolf Magnus Institute for Pharmacology, Medical Faculty, State University of Utrecht, Vondellaan 6, 3521 GD \\ Utrecht, The Netherlands
}

\begin{tabular}{|c|c|c|c|}
\hline \multicolumn{4}{|c|}{ ABBREVIATIONS } \\
\hline $\mathrm{ACTH}$ & Adrenocorticotropic Hormone & HO-DI & Homozygous diabetes insipidus \\
\hline CNS & Central Nervous System & HO-NO & Homozygous normal \\
\hline DALA & D-Ala ${ }^{2}$-Leucine $\mathrm{s}^{5}$-enkephalin amide & sIPSPs & \\
\hline $\begin{array}{l}\text { DADL } \\
\text { D.C. }\end{array}$ & $\begin{array}{l}\text { D-Ala }{ }^{2} \text {-D-Leucine }{ }^{5} \text {-enkephalin amide } \\
\text { Direct Current }\end{array}$ & IU & $\begin{array}{c}\text { Potentials } \\
\text { International Unit }\end{array}$ \\
\hline $\mathrm{DH}$ & Dorsal Horn & LE & Leucine ${ }^{5}$-Enkephalin \\
\hline DR & Dorsal Root & LC & Late Component \\
\hline DRPs & Dorsal Root Potentials & LS & Lateral Septum \\
\hline $\mathrm{DT} \alpha \mathrm{E}$ & Des-Tyr $-\alpha$-Endorphin & $\beta$-LPH & $\beta$-Lipotropic Hormone \\
\hline $\mathrm{DT} \gamma \mathrm{E}$ & Des-Tyr'- $\gamma$-Endorphin & LSC & Lateral Septal Complex \\
\hline$\beta \mathbf{E}$ & $\beta$-Endorphin & $\mathrm{ME}$ & Methionine ${ }^{5}$-Enkephalin \\
\hline ECoG & Electrocorticogram & MEA & Methionine ${ }^{3}$-Enkephalin Amide \\
\hline EEG & Electroencephalogram & MR & Membrane Resistance \\
\hline EPs & Evoked Potentials & MUA & Multiple Unit Activity \\
\hline EPSPs & Excitatory Postsynaptic Potentials & $\mathrm{N}$ & Negative \\
\hline sEPSPs & Slow Excitatory Postsynaptic & OX & Oxytocin \\
\hline & Potentials & $\mathbf{P}$ & Positive \\
\hline$K(33-824)$ & (D-Ala ${ }^{2}$, N-ME Phe & RMP & Resting Membrane Potential \\
\hline & Met- $(O)^{5}$-al)-enkephalin & SG & Sympathetic Ganglion \\
\hline FW (34-569) & (Me-Tyr', D-Ala ${ }^{2}, N-$ MePhe $^{4}$ & SWS & Slow-Wave Sleep \\
\hline & kephalin & TTX & Tetrodotoxin \\
\hline BA & $\gamma$-aminobutyric acid & VPL & Ventral Posterior Lateral \\
\hline & Heterozygous diabetes insipidus & & \\
\hline
\end{tabular}

\section{INTRODUCTION}

The pituitary gland elaborates and releases peptides and these peptides may alter various brain functions by acting within the brain. This appeared for the first time in experiments with animals whose pituitary gland had been removed. Hypophysectomized rats had an impaired acquisition and maintenance of the shuttle-box avoidance response and the impaired avoidance behavior could be corrected temporarily by injecting the animals with the adrenocorticotropic (ACTH) or melanocyte-stimulating (MSH) hormones from the pituitary (de Wied, 1969). Subsequently it was found that fragments of these hormones, that lack the classical endocrine effects (as for example $\mathrm{ACTH}_{4-10}$ ) act on behavior in intact rats, therefore these pituitary peptides must have acted at least partly within the brain. These and other experiments (de Wied, 1974) led to the hypothesis (de Wied, 1969) that pituitary hormones function as precursors for shorter peptides designated as neuropeptides and that in turn these neuropeptides act upon the brain and thus may influence its function.

In 1975 Hughes and his co-workers (Hughes, 1975; Hughes et al., 1975) discovered two endogenous pentapeptides with opiate-like analgesic activity. The structure of the pentapeptides appeared to be identical with the 61-65 amino acid residues of the pituitary $\beta$-lipotropic hormone $(\beta$-LPH) molecule. These observations directed attention to $\beta$-LPH. It was soon found that the C-terminal part of the $\beta$-LPH molecule $\left(\beta-\mathrm{LPH}_{61-91}\right)$ referred to as $\beta$-endorphin $(\beta E)$, resembled the enkephalins in its affinity for the stereospecific opiate receptors and in inducing analgesia (Bradbury et al., 1976a, b). Subsequently, it was 
suggested that $\beta$-LPH and ACTH were parts of a much larger protein (Mains et al., 1977; Orth and Nickolson, 1977) histochemically detectable in cells of the pituitary gland and in some hypothalamic neurons located within the anatomical borders of the arcuate nucleus (Bloom et al., 1978, 1979; Dupont et al., 1980). The structure of this peptide is presented in Fig. 1 as it was first proposed by Nakanishi et al. (1979). In addition to $\beta$-LPH, the peptide contains the amino acid sequences of ACTH and MSH and could thus function as precursor for these peptides. The release of $\beta$-LPH, ACTH and MSH from the pituitary indeed appeared to be controlled by the same mechanism (Guillemin et al., 1978). Accordingly, the peptide was named pro-opiocortin or pro-opiomelanocortin.

Exposure of $\beta \mathrm{E}\left(\beta-\mathrm{LPH}_{61-91}\right)$ to enzymes associated with enriched synaptosomal plasma membranes from rat brain yielded a number of shorter peptides (Burbach et al., 1980). Some of these peptides, e.g. $\gamma$-endorphin $\left(\gamma \mathrm{E} ; \beta\right.$ - $\left.\mathrm{LPH}_{61-77}\right)$, Des-Tyr ${ }^{1}-\gamma \mathrm{E}$ (DT $\gamma \mathrm{E}$; $\beta$ - $\left.\mathrm{LPH}_{62-77}\right)$ and $\alpha$-endorphin $\left(\alpha \mathrm{E} ; \beta-\mathrm{LPH}_{61-76}\right)$ or Des-Tyr ${ }^{1}-\alpha \mathrm{E}\left(\mathrm{DT} \alpha \mathrm{E} ; \beta-\mathrm{LPH}_{62-76}\right)$ could be differentiated by assessing their biological activities in various behavioral procedures (for review see de Wied and Jolles, 1982). It was therefore suggested that on its release from neurons, pro-opiocortin is degraded into fragments which modulate complex brain functions underlying behavioral adaptation (de Wied and Jolles, 1982). The alterations in brain functions that follow the administration of peptides and that can be measured with behavioral procedures should also be measurable with electrophysiological techniques. Experiments with electrophysiological techniques, and designed to examine the influence of peptides on brain processes describable in neurophysiological terms are the topic of the present review.

There are mainly historical reasons for separating the studies analysing the effects of ACTH- and MSH-related peptides from those dealing with the action of endorphins and enkephalins. Enkephalins are presumably formed from a molecule different from the pro-opiocortin molecule since enkephalin-like immunoreactivity was found in neurons that failed to react with $\beta \mathrm{E}$ antisera (Bloom et al., 1978). However, the endorphins often resemble the enkephalins in their effects on single neurons, suggesting that both types of peptides may have a similar mode of action. The action of enkephalins on single cells has been analysed in great detail (for review see Frederikson, 1977; Bradley et al., 1978a,b; North, 1979; Zieglgänsberger and Fry, 1978; Zieglgänsberger, 1980) and discussing the action of enkephalins may therefore be of relevance to the question of endorphins. A short discussion of the methods is included for those readers who are less familiar with procedures used in electrophysiological experiments.

\section{METHODOLOGY}

\subsection{Macroelectrophysiological Measurements of Neuronal Processes}

The electroencephalogram (EEG), electrocorticogram (ECoG), evoked potentials (EPs) and multiple-unit activity (MUA) are the macroelectrophysiological measurements most often used for studying the action of drugs on the brain in vivo.

\subsubsection{The Electroencephalogram (EEG)}

This is the time history of the potential differences recorded between electrodes in contact with, or in close proximity to brain tissues, and the reference electrode placed at some remote, electrically inactive site. The EEG reflects the global synaptic activity of a large neuron population, and as such provides an index of brain function. As it is a complex parameter whose morphology changes continuously along the wakefulness-sleep continuum, the EEG allows no simple interpretation. Neuropharmacological studies investigating drug effect on this parameter are therefore mostly limited to comparisons of spontaneous EEG activity under control (no drug) conditions with the activity recorded following drug treatment. Some kind of EEG quantification is necessary for such a comparison. Until recently, EEG signals were mostly evaluated by visual inspection and manual measurement of the main variables, the amplitude and frequency. For this 
Met-Pro-Arg-Leu-Cys-Ser-Ser-Arg-Ser-Gly-Ala-Leu-Leu-Leu-Ala-Leu-Leu-Leu-GIn-Ala $-120$

Ser-Glu-Thr-Thr-Leu-Asp-Gln-Sys-Gln-Ser-Ser-Glu-Leu-Cys-Trp-Gly-Arg-Val-Glu-Met I Asn

Leu-Leu-Ala-Cys-I le-Arg-Ala-Cys-Lys-Pro-Asp-Leu-Ser-Ala-Glu-Thr-Pro-Val-Phe-Pro GAMMA-MSH

Arg-Phe-His-Gly-Met-Val-Tyr-Lys-Arg-Pro-Asn-Glu-Thr-Leu-Pro-Gln-Glu-Asp-Gly-Asn Trp

Trp

I

Asp-Arg-Phe-Gly-Arg-Arg-Asn-Gly-Ser-Ser-Ser-Ser-Gly-Val-Gly-Gly-Ala-Ala-Gln-Lys $-40$

Gly-Thr-Glu-Ala-Asp-Asp-Gly-Arg-Pro-Gly-Pro-Gly-Glu-Gly-Val-Ala-Val-Glu-Glu-Glu I Pro CORTICOTROPIN $1-39$

Arg-Glu-Asp-Lys-Arg-Ser-Tyr-Ser-Met-Glu-His-Phe-Arg-Trp-Gly-Lys-Pro-Val-Gly-Lys $-1 \quad 1$ ALPHA-MSH

Pro-Phe-Ala-Gln-Ala-Ser-Glu-Asp-Glu-Ala-Gly-Asn-Pro-Tyr-Val-Lys-Val-Pro-Arg-Arg Leu BETA-LIPOTROPIN $42-132$ LeU CLIP GAMMA-LIPOTROPIN 42-99

Glu-Phe-Lys-Arg-Glu-Leu-Ala-Gly-Ala-Pro-Pro-Glu-Pro-Ala-Arg-Asp-Pro-Glu-Ala-Glu 39 42

Ala-Ala-Glu-Ala-Glu-Ala-Glu-Ala-Val-Leu-Gly-Tyr-Glu-Leu-Glu-Ala-Arg-Ala-Ala-Ala I

Glu BETA-MSH

Lys-Lys-Asp-Ser-Gly-Pro-Tyr-Lys-Met-Glu-His-Phe-Arg-Trp-Gly-Ser-Pro-Pro-Lys-Asp 80 BETA ENDORPHIN —_ Lys

Lys-Phe-Leu-Thr-Val-Leu-Pro-Thr-Gln-Ser-Lys-Glu-Ser-Thr-Met-Phe-Gly-Gly-Tyr-Arg Asn 120

1 METENKEPHALIN -

Ala-I le-I le-Lys-Asn-Ala-His-Lys-Lys-Gly-Gln

Fig. 1. Primary structure of bovine pro-opiomelanocortin molecule. The molecule incorporates gamma-MSH, ACTH (corticotropin, 1-39) and beta-lipotropin ( $\beta$-LPH; 42-132). The alpha-MSH (1-13) and CLIP (18-39) sequence can be recognized in the corticotropin chain. $\beta$-LPH incorporates gamma-lipotropin (42-99), the sequence of beta-MSH (82-99) and the 31 amino acid long chain of beta-endorphin $(\beta E ; 102-132) . \beta E$ in turn incorporates the sequence 102-106 of enkephalin (adapted from Bloom, 1981).
Ala-Alanine
Arg-Arginine
Asn-Asparagine
Asp-Aspartate
Cys-Cysteine
Gln-Glutamine
Glu-Glutamate
Gly-Glycine
His-Histidine
Ile-Isoleucine

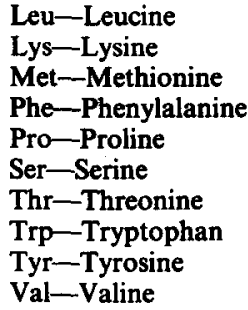


purpose, the frequency scale was divided into a number of frequency bands which were given the following Greek notation: delta band, for the activity under $3.5 \mathrm{~Hz}$; theta band, for activity from 3.5 to $7.0 \mathrm{~Hz}$; alpha band, frequencies from 8 to $13 \mathrm{~Hz}$ and beta band, for activity above $13 \mathrm{~Hz}$. Visual analysis consisted in determining the amount and the peak-peak amplitude of activity in these bands by measuring the peaks in the polygraph records. In addition to these quantitative expressions, a number of qualitative terms are used to describe the wave-forms in the EEG, e.g. spike and wave complex, K-complex, Mu-rhythm, spindles etc. Storm Van Leeuwen et al. (1966) and Chatrian et al. (1974) have provided glossaries of the terms used in animal and clinical electroencephalography. A number of these terms, e.g. synchronization, desynchronization, high voltage slow activity (HVSA), low voltage fast activity (LVFA), spindling are still commonly used in psychoneurophysiological and neuropharmacological descriptions of the EEG.

Digital computers have greatly improved the objectivity and resolution of EEG analysis. The speed and capacity of the computers to process several EEG channels in real time stimulated the development of new computer-assisted methods (Burch, 1959; Storm Van Leeuwen, 1964; Byford, 1965; Schallek et al., 1967; Fink, 1968; Fairchild et al., 1971; Matousek, 1973; Itil, 1974; Künkel, 1977; Matejcek and Devos, 1976; Haller, 1979) for quantifying the EEG. These methods consist in computing some kind of EEG estimate describing the amplitude and frequency of the EEG signals using a single set of numbers that is readily amenable to further statistical comparisons. Automatized EEG analysis has opened a new approach in CNS pharmacology; quantitative pharmacoeletroencephalography. This approach evaluates drug action according to the significance of changes that occur in various frequency bands of the spontaneous human EEG following administration of the drug to be tested. It was quantitative pharmacoelectroencephalography which led to the finding that therapeutically equivalent compounds, even if they are pharmacologically different, will still produce similar changes in the spontaneous human EEG (Itil, 1974). Thus, drugs classified as tranquillizers according to their clinical effects had EEG profiles that contained significantly lower amounts of the very low (delta, theta and alpha) frequencies and greater proportions of the fast frequencies (Schallek and Keuhn, 1959; Fink, 1968; Joy et al., 1971; Itil, 1974) than did 'placebo profiles'. The neuroleptics (major tranquillizers) enhanced the production of slow (delta, theta) waves and suppressed the fast activity (Fink, 1968; Itil, 1974), whereas most of the psychostimulants (thymoleptics) decreased the slow delta activity and decreased the intensity of the EEG signal (Fink, 1974). Interestingly, the EEG profiles of diazepam, chlorpromazine and $\alpha$-amphetamine found in cat EEG (Haller, 1979) were similar to those based on the human EEG, suggesting that the action of many psychoactive agents on brain may be similar across species and that the results obtained in the animal studies may be relevant to humans.

\subsubsection{Evoked Potentials (EPs)}

Measuring different kinds of cortical EPs before and after administering centrally acting drugs is another macroelectrophysiological approach to the study of drug action on the brain (for review see Shagass, 1977). Cortical evoked potentials, sometimes also termed the event-related potentials, are EEG segments which are time-locked to a repetitive (sensory) stimulus. Averaging of these segments is often necessary to increase the signal-noise ratio, so that the evoked potential is sufficiently enhanced to become visible against the background EEG. An EP normally consists of a number of positive and negative waves (components) that appear at different latencies following the stimulus. The drug-induced alterations in amplitude, form and latencies of these components may therefore be used for evaluating the drug effect on the brain. Saletu (1974) examined the human somato-sensory EPs following treatment with various psychoactive agents. A standard procedure was used for inducing the EPs: identical placement of the recording electrodes, controlled level of vigilance and identical data processing. The drugs used for similar clinical purposes produced similar alterations in EPs and the authors thus 
suggested, that this method was applicable for classification and/or prediction of the therapeutic effects of new psychoactive agents.

Different waves in the EPs are presumably related to different neuropsychological and/or psychophysiological processes. Several early (with latency shorter than $60 \mathrm{msec}$ ) and late (latency longer than $60 \mathrm{msec}$ ) waves could be distinguished in EPs that could be recorded above the somatosensory cortex following stimuli applied to the medial nerve. According to Allison et al. (1977) the positive wave P15 that occurs in EPs at $15 \mathrm{msec}$ after a stimulus is related to the volley in afferent fibers terminating on neurons of the ventrobasal posterior lateral (VPL) thalamic nucleus, to the synaptic events in this nucleus and to the action potentials in the thalamo-cortical fibers. The subsequent negativepositive waves with latency between $20-60 \mathrm{msec}$ reflect the primary response in the somato-sensory cortex. An effect of drugs on these short-latency components would therefore indicate an alteration in synaptic transmission in the thalamus or in the primary somato-sensory areas. The late components, e.g. the positive P180 wave in these EPs could be markedly augmented by asking the subjects to concentrate fully on the stimulus (Satterfield, 1968), suggesting that the magnitude of these components expresses the amount of selective attention in these subjects. The drug-induced alteration in P180 and other late components could thus be interpreted as a drug effect on selective attention.

\subsubsection{Multiple-Unit Activity (MUA)}

For technical details of this technique see, e.g. Buchwald et al., 1973. This is a measure of the frequency of action potentials that could be recorded extracellularly and within the selected time interval from an unknown population of spontaneously active or stimulusdriven neurons. Like the EEG, the frequency of MUA varies with fluctuations in the subject's vigilance and thus may be a useful means for signalling the action of drugs on the vigilance regulating systems. It should be realized that the stimulus- or the druginduced excitation of one kind of neurons in one structure is likely to be associated with inhibition of other kinds of neurons within the same structure. MUA will register only a net change in total number of action potentials per unit time; this change could be nil, close to zero or so small that it remains buried in the fluctuations of 'baseline' activity. It is perhaps for this reason that MUA is not frequently use in neuropharmacological studies.

\subsection{Microelectrophysiological Measurements of Neuronal Processes}

Microelectrophysiological techniques allow the action of compounds to be studied at the subcellular level, either in vivo or in vitro. Studies in vivo usually involve extracellular recordings of action potentials from the spontaneously or stimulus-driven single neuron before, during and after administration of a test compound. The compound may be given systemically (s.c., i.p. or i.v.), injected in small volumes into the intracerebroventricular system, administered directly into a selected brain structure, or applied by microiontophoretic or pressure injections in the vicinity of the neurons being used for recording. Compounds that pass through the blood-brain barrier can be given systemically. This route of administration may be preferred for its simplicity and because the compound can be given in doses which induced the desired behavioral effects. While i.c.v. injections circumvent the blood-brain barrier, one cannot decide whether the compound has changed neuronal activity by acting directly on the recorded neuron or at some other place remote to the recording site. An intracerebrally administered substance acts primarily at the locus of injection. It should be kept in mind that the effects following administration via this route may be merely pharmacological or toxic effects of the drug and unrelated to the behavior in question. The microiontophoretic procedure (for details see Curtis, 1964) consists of expelling drug ions from one barrel of a micropipette filled with an aqueous solution of the drug by passing through this barrel a small current of the same polarity as the ions, and concommittantly recording the activity of the neuron through another barrel of the micropipette. 
In vivo iontophoretic drug application is superior to any other route of administration in that it eliminates the interference of the blood-brain and enzymatic barriers and allows the neurons to be studied under almost natural conditions with intact synaptic inputs. The value of microiontophoresis increases further if the cells under study can be identified functionally (by specific stimuli) or electrophysiologically (using electrical stimulation of known synaptic inputs). However, it is very difficult to determine and to control the actual concentration of iontophoretically applied drugs at the receptor sites. This is due to many factors (for review see Bloom, 1975) some of which, e.g. diffusion, metabolic degradation and uptake of the drug by neural tissue, cannot be controlled by the investigator. Microiontophoresis is therefore less suited for pharmacological studies involving dose-response relationships, agonist-antagonist interaction or for comparing relative potencies of drugs.

\subsubsection{Studies In Vitro}

Neural tissues maintained in vitro provide an excellent preparation for use in pharmacological experiments as the drug concentration in the incubating medium also becomes the actual concentration of the substance at the receptor sites. In addition, the in vitro arrangement permits long-term intracellular recordings from single neurons without interference by anesthesia or transsynaptic activities and allows the ionic mechanisms of drug action to be elucidated. Results obtained in vitro must eventually be confirmed in vivo as neurons in vitro may behave differently from those in situ.

\section{EFFECTS OF ACTH/MSH PEPTIDES ON MACROELECTROPHYSIOLOGICAL MEASUREMENTS}

\subsection{EEG}

The EEG was first used to study the central action of peptides in experiments on the influence of ACTH on experimentally induced seizure-like activity. A single injection of ACTH $(1-8 \mathrm{mg} / \mathrm{kg})$ to rats could significantly lower the threshold for induction of epileptoid seizures and convulsions produced with pentamethylene tetrazol (Torda and Wolff, 1952a). Adrenalectomy or hypophysectomy had no effect on the response to ACTH indicating a direct, extra-adrenal effect of ACTH in the brain, Wasserman et al. (1965) elicited seizure activity with an electric shock delivered transcorneally to intact or adrenalectomized rats maintained on a sodium rich diet. Less current was needed to elicit seizures in both experimental groups if they had received 5 IU of ACTH daily for one week prior to the test. ACTH also increased the intracellular $\mathrm{Na}^{+}$concentration in brain, regardless of whether or not the adrenals had been removed. Thus, ACTH may have affected the susceptibility to develop seizures by interfering with processes which regulate the cellular distribution of $\mathrm{Na}^{+}$. Donaldson et al. (1971) found that the intracerebral administration of ouabain, a $\mathrm{Na}^{+}$pump inhibitor, induced seizure activity in rats. Interestingly, the onset of the ouabain-provoked seizures could be greatly accelerated by prior treatment of the rats with $\alpha$-MSH (Izumi et al., 1973). In contrast to experimentally induced epilepsy in animals, which was enhanced by ACTH (see also Woodbury, 1958), human epilepsy was only aggravated by ACTH in patients suffering from the grand mal form of the illness. In fact, treatment of young (under 15 years of age) patients with ACTH ameliorated the clinical and electrophysiological symptoms of petit mal epilepsy in nearly $65 \%$ of the cases (Gestaut et al., 1959). According to EEG records obtained from 143 petit mal epileptic children, $23 \%$ of the patients were cured following a 10 day treatment with ACTH, 43\% exhibited marked improvement and the symptoms showed no change or worsened in $34 \%$ (Klein, 1970). Different mechanisms for experimentally induced seizure activity and pathological human epilepsy (Schmidt and Wilder, 1968) may perhaps account for the dissimilar action of ACTH on this abnormal activity in experimental animals and in humans. Nevertheless, these and other studies (Glaser, 1953; Glaser et al., 1955) have shown that ACTH may change brain electrical activity in both humans and experimental animals by acting directly upon the brain. 
Physiological EEG activity could also be altered by peptides related to ACTH. Kawakami et al. (1966) recorded the spontaneous EEG from several subcortical structures in freely moving rabbits. In many structures the frequency composition of the spontaneous activity changed after i.v. injections of ACTH. Thus, treatment with the peptide decreased the theta and $20-60 \mathrm{~Hz}$ activities in the hippocampus and increased the amounts of 4-13 and $20-60 \mathrm{~Hz}$ activities in the baso-lateral amygdala. The anterior hypothalamic area was dominated by the slow $4-13 \mathrm{~Hz}$ activity. The initial increase in the $2-8 \mathrm{~Hz}$ band which occurred in the medial preoptic area in the first $60 \mathrm{~min}$ after the injection was later replaced by a marked decrease in this band. The activities in the median eminence and arcuate nucleus remained depressed for $3 \mathrm{hr}$ after ACTH was given. ACTH did not change the EEG of the posterior hypothalamic area and mamillary bodies but slightly increased the 4-8 Hz waves in the mesencephalic reticular formation. The frog preoptic area generated more 4-9 $\mathrm{c} / \mathrm{sec}$ waves after $\alpha-\mathrm{MSH}$ injection to the dorsal lymph sac than prior to the treatment (Denman et al., 1972). However, Sawyer et al. (1968) saw only neocortical desynchronization subsequent to $2 \mathrm{IU}$ of ACTH, and Pfaff et al. (1971) failed to detect any alterations in cortical EEG records even after injecting the rats with 10-20 IU of the peptide. On visual inspection of EEG records, Dyster-Aas and Krakau (1965) found the marked increase in slow wave cortical activity subsequent to s.c. injection of $10 \mathrm{mg} \alpha-\mathrm{MSH}$ to intact rabbits. The natural $\alpha-\mathrm{MSH}$ and $\beta-\mathrm{MSH}$, as well as the synthetic $\alpha-\mathrm{MSH}$, promoted the $4-9 \mathrm{~Hz}$ slow activity in the parietal EEG of rats (Sandman et al., 1971). In a double blind experiment on six healthy volunteers, panhypopituitarism patients and two patients with Sheeman's syndrome, the i.v. infusion of saline containing $10 \mathrm{mg}$ of $\alpha$-MSH slowed down the spontaneous occipital EEG (Velasco et al., 1972). Recently, Miller et al. (1981) re-examined the action of $\alpha-\mathrm{MSH}$ on the spontaneous EEG of rats and used a more objective spectral analysis for quantification. The occipital power spectra of rats treated i.p. with $80 \mu \mathrm{g} / \mathrm{kg}$ of the peptide had a markedly increased intensity in the $2-5 \mathrm{~Hz}$ band and a mildly increased power in the $7-10 \mathrm{~Hz}$ band. In the EEG recorded sagitally at $\mathrm{Cz}$ and $\mathrm{Oz}$ positions in the scalp of elderly male and female volunteers suffering from mild symptoms of organic brain disease, $30 \mathrm{mg}$ of $\mathrm{ACTH}_{4-10}$ given s.c. significantly increased the proportion of delta $(1-3 \mathrm{~Hz})$ and theta $(3-7 \mathrm{~Hz})$ activities and decreased the amount of $\alpha$ and $\beta$ activities. The female patients in this study appeared to be significantly more sensitive to $\mathrm{ACTH}_{4-10}$ than the male subjects (Braconnier et al., 1979).

Diversity in the experimental procedures must account at least in part for the great diversity in EEG patterns obtained in these experiments with peptides. Rockstroh et al. (1981) examined the effect of the orally active $\mathrm{ACTH}_{49}$ analog (Org 2766) on the frontal, precentral and parietal EEG recorded from young healthy volunteers during $6 \mathrm{sec}$ epochs separating the warning and the test stimuli. In this case, the ACTH analog significantly increased the low $(8-10 \mathrm{~Hz})$ alpha frequencies and decreased the intensity of the signal in the $2-24 \mathrm{~Hz}$ band. In a different test situation (Miller et al., 1974), ACTH ${ }_{4-10}$ significantly decreased the activity in the $3-7 \mathrm{~Hz}$ band but augmented the duration and amplitude of activity in the $7-12 \mathrm{~Hz}$ band and in the band above $12 \mathrm{~Hz}$. Clearly, in many cases, the peptides themselves did not elicit a particular EEG pattern just as they did not elicit a particular behavioral pattern (for review see de Wied and Jolles, 1982). They only modified the behavioral and EEG patterns induced by a particular experimental procedure.

Repeated presentation of a familiar tone to human volunteers elicited $\alpha$-synchronized activity in the occipital scale EEG. $\mathrm{ACTH}_{1-24}$ and $\mathrm{ACTH}_{1-10}$ i.v. in doses of 1-2 mg could suppress this stimulus-induced $\alpha$-synchrony. The $\mathrm{ACTH}_{11-24}$ sequence, which was only weakly active in behavioral procedures (de Wied, 1979), failed to affect this measure (Endröczi et al., 1970). In another double blind study on 20 healthy young volunteers, $\mathrm{ACTH}_{4-10} \mathrm{mg}$ injected i.v. was also effective in blocking the stimulus-induced occipital alpha rhythm in the peptide-treated subjects (Miller et al., 1974). Thus, the peptides that elicit similar effects in the same behavioral test situation may elicit similar effects in the same electrophysiological test.

ACTH and related peptides delay the extinction of avoidance behavior, presumably by acting on the midbrain limbic system (for review see de Wied and Jolles, 1982). 
Hippocampal theta activity is an excellent macroelectrophysiological parameter for studing the functioning of this system. This rhythmic field is generated by a synchronous input arriving at the hippocampal formation from the septum (Petsche et al., 1962; Gogolak et al., 1967, 1968). In order to produce a synchronous input, the septal network needs excitation from the brain stem afferents (Green and Arduini, 1953; Klemm, 1970, 1971, 1972a, b; Paiva et al., 1976). Urban and de Wied (1976) elicited theta rhythm in the hippocampus and posterior thalamus of freely behaving rats by stimulating the mesencephalic reticular formation with constant stimuli at $100 \mathrm{~Hz}$. Treating the rats with $\mathrm{ACTH}_{4-10} 150 \mu \mathrm{g} / \mathrm{kg}$ body weight increased the peak and mean frequencies of the stimulus-induced hippocampal synchrony by approximately $0.5 \mathrm{~Hz}$ (see Fig. 2). The peptide-induced acceleration of theta rhythm appeared 30-60 min following the injection and persisted for several hours. A similar acceleration of hippocampal rhythmicity was obtained by mildly $(10 \mu \mathrm{A})$ increasing stimulus intensity. On the assumption that the stronger stimulus engaged a greater number of mesencephalic units in generating theta rhythm it was suggested that $\mathrm{ACTH}_{4-10}$ accelerated hippocampal activity by increasing the excitability of those units.

Theta activity occurs spontaneously in moving rats or during paradoxical sleep (PS). In moving rats, the frequency of this activity may vary rapidly between $6-12 \mathrm{~Hz}$ depending on the velocity and intensity of the movement (Whishaw and Vanderwolf, 1973). The frequency of the theta rhythm which accompanies PS is similar to the electrically elicited rhythmicity in that it is very stable, remaining unchanged for most of the duration of PS episodes. The large narrow peak at $7.5-8.0 \mathrm{~Hz}$ and the negligible amounts of activity in other frequency bands in the power spectra of PS activity (Urban, 1981) indicate uninterrupted, intense and presumably exclusive activation of the midbrain-septo-hippocampal system during the PS episodes. These episodes are therefore very well suited for examining the effect of $\mathrm{ACTH}_{4-10}$ on the midbrain limbic system under physiological conditions. Urban and de Wied (1975) found that during PS the mean theta frequency in Brattleboro rats homozygous for hypothalamic diabetes insipidus (HO-DI) was $0.7-1.0 \mathrm{~Hz}$ lower than that of the heterozygous litter mates (HE-DI) or homozygous normal (HO-NO) rats. Microinjections i.c.v. of $20 \mathrm{ng} \mathrm{ACTH} \mathrm{Al}_{4-10}$ temporarily raised the rate of hippocampal rhythmicity of HO-DI rats to the levels found in HE-DI or HO-DO rats. The same dose of $\mathrm{ACTH}_{4-10}$ administered to HE-DI rats increased further the amounts of high theta frequencies in these animals (Urban and de Wied, 1978). Thus, irrespective of the dose and route of administration, $\mathrm{ACTH}_{4-10}$ accelerated both electrically elicited and PS-induced theta activities.

There has been no detailed investigation of the relationship between the structure of peptides and their capacity to accelerate hippocampal rhythmicity. Two important pieces of evidence however suggest that the relationship may resemble that revealed in avoidance behavior procedures. The amino acid residue phenylalanine in position 7 is essential for the effect of $\mathrm{ACTH}_{4-10}$ on extinction of avoidance behavior (de Wied, 1969). When the phenylalanine residue was replaced by its D-enantiomer the peptide (D-Phe ${ }^{7}$ ) $\mathrm{ACTH}_{4-10}$ was generated. It had effects on avoidance behavior opposite to those of the non-substituted, all $\mathrm{L} \mathrm{ACTH} \mathrm{AH}_{4-10}$ and facilitated extinction of the pole jumping response. When injected in the same amount as $\mathrm{ACTH}_{4-10}$, (D-Phe $\left.{ }^{7}\right) \mathrm{ACTH}_{4-10}$ slowed down PS hippocampal theta rhythm. ACTH $\mathrm{Al}_{1-24}$ was only weakly active in avoidance procedures (de Wied, 1979). $\mathrm{ACTH}_{11-24}, 20 \mu \mathrm{g}$ injected i.c.v. failed to alter the frequency composition of hippocampal activity during PS (Urban and de Wied, 1978).

The frequency composition of the spontaneous and slow wave sleep (SWS) hippocampal EEGs is much more complex than that of the stimulus or the PS-induced theta synchronies. In addition to theta activity, they contain a large quantity of delta (1-4) $\mathrm{Hz}$ waves and significant amounts of frequencies above $12 \mathrm{~Hz}$. Several other systems in addition to the theta producing network must therefore participate in the genesis of these EEGs. Interestingly, the spontaneous EEGs recorded from the rat hippocampus during the intervals separating the stimulation trials (Urban and de Wied, 1976) or during SWS episodes (unpublised observation) were little affected by $\mathrm{ACTH}_{4-10}$. A striking feature of 

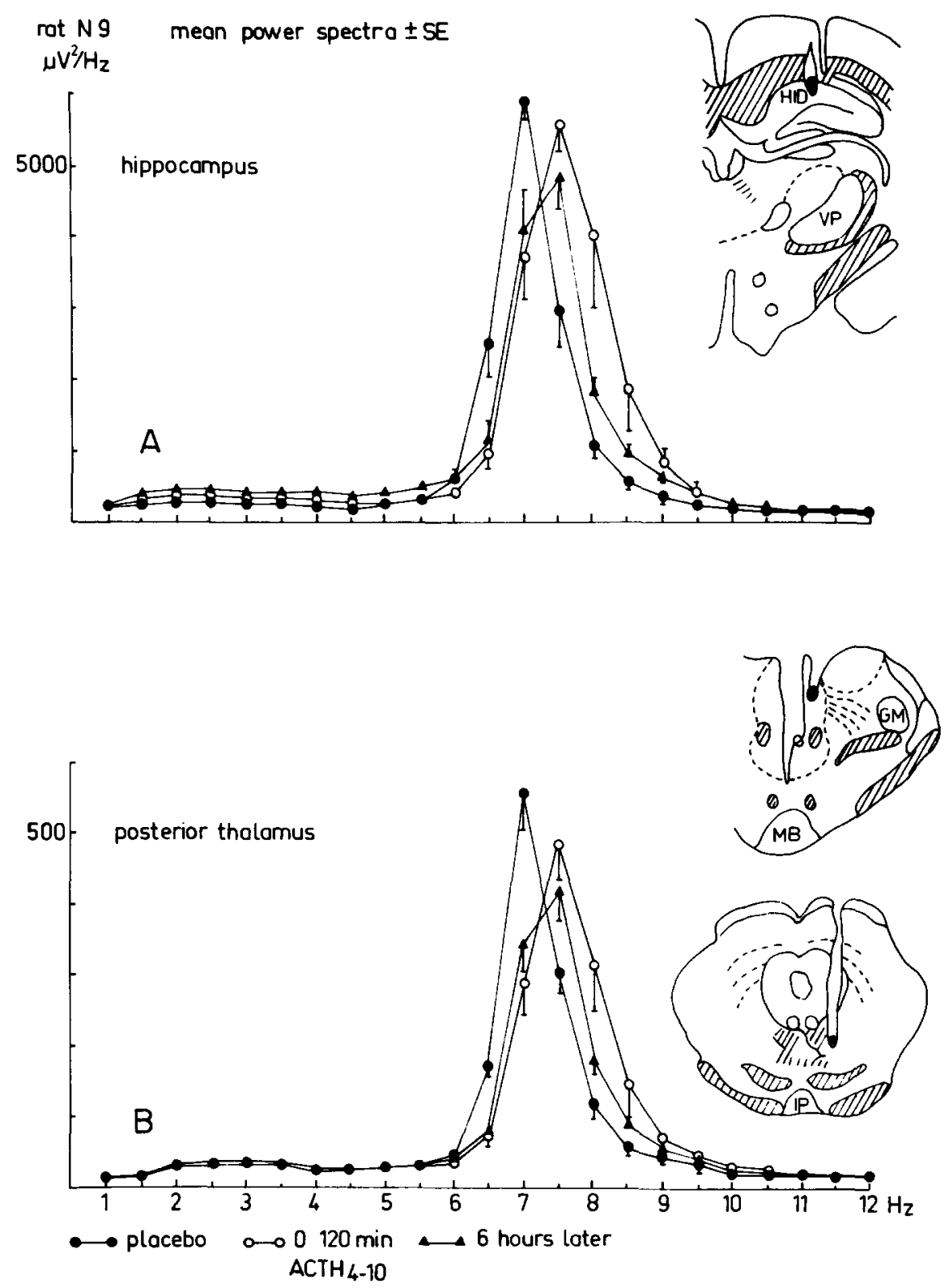

Fig. 2. Effect of subcutaneously injected $\mathrm{ACTH}_{4-10}(150 \mu \mathrm{g} / \mathrm{kg})$ on the mean power spectrum $( \pm$ S.E.M.) of the dorsal hippocampus and posterior thalamus theta activity induced by stimulating $(50 \mu \mathrm{A})$ the mesencephalic reticular formation of a freely behaving rat. Inset in A depicts the localization of the recording electrode in the dorsal hippocampus (HID); upper inset in B illustrates the placement of the recording electrode in the posterior thalamus, lower inset in B indicates placement of the stimulating electrodes (according to Urban and de Wied, 1976).

these EEGs was that the amounts of activity in various frequencies fluctuated markedly from episode to episode and that the magnitude of the fluctuations in one particular frequency band could largely exceed the magnitude of any change that $\mathrm{ACTH}_{4-10}$ could induce in the theta band. Any effect of the peptide under these conditions would presumably have stayed below the detection limit. Two important conclusions follow from these experiments. First, the effects of ACTH-like peptides on a particular brain structure or system should be studied with the structure or system in full functional activity. Second, the action of these peptides is best studied with an experimental procedure in which only one structure or system is selectively activated at any one time. 
$\mathrm{ACTH}_{4-10}$ given s.c. significantly slowed down hippocampal theta rhythm, in a dog put in an operant condition test situation (Urban et al., 1974). Studies on rats suggested that the action of $\mathrm{ACTH}_{4-10}$ on the theta rhythm-producing midbrain limbic system is most probably an excitatory one. If the peptide were acting solely on this system, hippocampal theta frequency would be expected to increase following the injection of $\mathrm{ACTH}_{4-10}$. The opposite was found. Thus, in slowing down hippocampal rhythmicity, the peptide must have acted on, and promoted activity in structures inhibitory on the midbrain limbic system. The raphe nucleus might be one of these structures. Electrical stimulation of the raphé nucleus suppressed or completely abolished hippocampal synchronized activity (Maru et al., 1979; Yamamoto et al., 1979).

The qualitatively different effect of $\mathrm{ACTH}_{4-10}$ on hippocampal theta activity of rats and of dogs is perhaps another example of the capacity of the peptide to alter the functioning of brain systems or structures that were activated by a particular behavioral procedure. When the animal is awake, a sudden increase in the frequency of hippocampal theta activity is always associated with behavioral disinhibition, i.e. readiness of the animal to respond by movement to biologically significant stimuli. The decrease in the rate of hippocampal synchrony reflects behavioral inhibition and diminished readiness of the animal to move (Kamp et al., 1971; Whishaw and Vanderwolf, 1973; Black, 1976; Arnolds et al., 1979a,b). ACTH ${ }_{4-10}$ slowed down theta rhythm in a dog during behavioral episodes described as 'facing', i.e. attentively awaiting the onset of the conditioned stimulus announcing food presentation. In a mildly food-deprived animal, movement inhibition was thus the behavior relevant to the situation. It is therefore conceivable that the systems that elicit behavioral inhibition, and not the structures initiating movement must have been active for most of the duration of 'facing' episodes. The fact that $\mathrm{ACTH}_{4-10}$ induced slowing down of hippocampal theta activity during the 'facing' episodes indicates that the peptide increased the functional efficiency of the movement-inhibiting system and not that of the movement-initiating system.

A different action of ACTH-like peptides on the hippocampus was shown by Valero $e t$ al. (1977). They administered stimuli of different frequencies to the septum and measured the intensity of the current needed to elicit theta-like EEG synchrony. In untreated male rats, the $7.7 \mathrm{~Hz}$ stimulus required the lowest current for inducing hippocampal synchrony. ACTH and $\mathrm{ACTH}_{4-10}$ shifted the minimal current to $6.9 \mathrm{~Hz}$.

\subsection{EVOKed Potentials}

ACTH/MSH peptides may alter the EPs in various brain structures in experimental animals and human subjects. In one study on chickens, Koranyi and Endröczi (1970) found that $\mathrm{ACTH}$ and $\mathrm{ACTH}_{4-10}$ attenuated by approximately $50 \%$ the cortical EPs elicited in these animals by stimuli delivered to the midbrain reticular formation, In rats, light flashes induced EPs in the occipital cortex. When the light-induced EPs were averaged, there appeared several distinct components in these potentials. ACTH $\mathrm{AT}_{4-10}$ $(50 \mu \mathrm{g} / \mathrm{kg})$ had little effect upon the early components of the EPs but the peptide significantly attenuated the late positive-negative (P3, N3) waves in EPs irrespective of the stimulus intensity used to elicit these potentials. The (D-Phe) $\mathrm{ACTH}_{4-10}$ analog had a similar but weaker action on the late P3 and N3 waves (Wolthuis and de Wied, 1976). According to some investigators (Velasco et al., 1968), the decrease in amplitude of the late components (LC) in EPs is associated with an increase in the discharge rate of the reticulo-thalamic neurons whereas the increase in magnitude of LC reflects the decrease of neuronal activity within the system. Thus, ACTH-like peptides may have attenuated the LC in the cortical EPs by acting upon the non-specific reticulo-thalamic ascending systems and by increasing excitability of neurons belonging to this system.

Kastin et al. (1971) and Velasco et al. (1972) elicited complex EPs above the somatosensory cortex by stimulating the median nerve in fully attentive subjects (patients were instructed to respond by pressing a lever as soon as possible), during episodes of inattentiveness (the subjects were asked to remain quiet and ignore the stimulus) and in patients whose attention was drawn elsewhere (the stimulus was presented while the 
subjects were solving a verbal memory and visual retention test), i.e. 'distracted' subjects. EPs obtained from fully attentive subjects were characterized by the presence of late P4 and P5 waves of considerable amplitude. The inattentiveness of patients markedly diminished the size of these components and the distraction almost completely abolished the P4 and P5 components in the somatosensory EPs. A slow i.v. infusion of $\alpha$-MSH failed to alter the procedure-dependent incidence of P4 and P5 waves. However it diminished the latency and markedly augmented the size of these waves in EPs. The peptide-induced increase in magnitude of P4 and P5 was appreciably greater in the attentive subjects than in the inattentive ones, suggesting some influence of the peptides on attention processes. Rockstroh et al. (1981) studied the effect of the $\mathrm{ACTH}_{4-9}$ analog Org 2766 on human scalp acoustic EPs in a situation that required full attention from the subjects. The EPs elicited by acoustic stimuli above the frontal and parietal cortices showed an early negative N100 and late positive $\mathrm{P} 300$ waves. $\mathrm{ACTH}_{4-9}(\mathrm{Org} 2766), 40 \mathrm{mg}$ orally, decreased the latency and increased the magnitude of both $\mathrm{N} 100$ and P300. Thus, in two similar situations, both $\mathrm{ACTH}_{4-10}$ and $\mathrm{ACTH}_{4-9}$ affected two kinds of scalp EPs in a similar fashion i.e. decreased the latency and increased the amplitude of the principal late components.

When the task was more complex however, the effect of peptides on late components in EPs was much altered. Miller et al. (1976) presented irrelevant and relevant visual stimuli to their subjects. The subjects were asked to press a button only on appearance of the relevant stimulus. EPs above the occipital cortices were recorded with both kinds of stimuli. Irrespective of the relevance of the stimulus, ACTH $_{4-10}(30 \mathrm{mg}$ s.c.) increased the latency and decreased the amplitude of the late negative and positive components which were visible in EPs at latencies of about 250 and $400 \mathrm{msec}$. In addition, after treatment with the peptide, a new small negative component of EPs appeared about $350 \mathrm{msec}$ following the stimulus. Fehm-Wolfsdorf et al. (1981) studied the effect of $\mathrm{ACTH}_{4.9}$ when two other types of stimulus situations were used. They presented one of two acoustic S1 stimuli ( 400 or $1200 \mathrm{~Hz}$ tone) for $6 \mathrm{sec}$. Each S1 stimulus was followed by a neutral $(600 \mathrm{~Hz})$ or an aversive $(110 \mathrm{~dB}$ noise) S2 stimulus. The subjects were instructed to terminate the $\mathrm{S} 2$ stimuli by operating a microswitch. $\mathrm{ACTH}_{49}(\mathrm{Org} 2766)$ failed to alter the latency or amplitude of the late N100 and other waves in EPs elicited above the frontal and parietal cortices by the $\mathrm{S} 1$ stimulus. The P300 component which was augmented in the one-stimulus situation (Rockstroh et al., 1981), had a diminished amplitude in the two-way stimulus situation.

It has been hypothesized that ACTH/MSH-like peptides enhance attentional processes selectively (Kastin et al., 1971). One argument in favor of such an interpretation was the fact that the P4 and P5 waves in the somatosensory EPs whose amplitude was augmented by peptides, were most pronounced in the fully attentive subjects and absent in the 'distracted' individuals (Kastin et al., 1971; Velasco et al., 1972). Indeed, in a discriminative test situation designed to study selective attention and which resembled in many features that used by Fehm-Wolfsdorf et al. (1981), the P300 wave was much enhanced when the subjects were attentive (Hillyard et al., 1973). However, the peptide-induced enhancement of P4 and P5 waves in the somatosensory EPs (Kastin et al., 1971) and of N100 and P300 waves in the frontal and parietal acoustic EPs (Rockstroh et al., 1981) was found only in a simple stimulus-response situation. In the two-stimulus test situation which required perhaps even a higher degree of attention and vigilance, $\mathrm{ACTH}_{4-10}$ increased the latency and decreased the amplitude of the principal (negative and positive) late components (Miller et al., 1976), and $\mathrm{ACTH}_{4-9}$ suppressed the $\mathrm{P} 300$ wave (Fehm-Wolfsdorf, 1981). There is increasing evidence that the late components in the cortical EPs reflect, in addition to selective attention many other physiological processes (for review see John and Schwartz, 1978; Näätänen, 1975). Any attempt to interprete the peptide-elicited changes in morphology of late components as an action of the peptide on selective attention is therefore certainly a great oversimplification.

\subsection{Multiple-UNit ACtivity}

Four studies were found in which MUA was used for investigating the influence of 
ACTH and related peptides on the brain. ACTH ( 2 IU) injected s.c. in rats elicited a slight increase in MUA recorded through indwelling metal semi-microelectrodes in the zona incerta and arcuate nucleus. Injections of $10 \mu \mathrm{g} \mathrm{ACTH}_{1-24}$ into the cerebroventricular system of rabbits elevated the frequency of the MUA in the lateral preoptic and diagonal band of Broca areas. $\mathrm{ACTH}_{4-10}$ failed to affect activity in this region (Baldwin et al., 1974). In cats, ACTH increased MUA only in the mesencephalic reticular formation, but limbic forebrain activities measured in the septum in the medial preoptic area were slightly decreased by this peptide (Koranyi et al., 1971a, b).

\section{EFFECTS OF ACTH/MSH PEPTIDES ON MICROELECTROPHYSIOLOGICAL MEASUREMENTS}

\subsection{Single NeURONS IN VIVO}

ACTH and some related peptides may enhance the spontaneous or the stimulus-induced activity of single neurons in several neurons in several brain structures. Thus, the firing rate of hypothalamic neurons increased shortly (2-3 min) after i.v. injection of ACTH (Van Delft and Kitay, 1972) just as did the activity of some hippocampal cells that could be recorded before and after the i.p. injection of 10-50 IU of ACTH (Pfaff et al., 1971). Microiontophoretic administration of ACTH yielded results similar to those of systemic injections. Steiner (1970) observed increased activity in a small number of diencephalic neurons during the iontophoretic release of $\mathrm{ACTH}$ in the vicinity of these neurons. In the medulla also, the spontaneous activity of some otherwise unidentified neurons was seen to increase in a dose-dependent manner during iontophoresis of $\mathrm{ACTH}_{1-24}$ onto these neurons (Gent and Normanton, 1980). In this experiment, the shorter amino acid sequences such as $\mathrm{ACTH}_{1-10}, \mathrm{ACTH}_{4-10}$ or $\mathrm{ACTH}_{4-7}$ did not change the firing rates of the neurons even when the peptides were applied with currents of up to $200 \mathrm{nA}$ for several minutes. The rate of firing of the hippocampal neurons did not change during direct, iontophoretic administration of the whole ACTH sequence. When the peptide was applied simultaneously with noradrenaline (NA), it antagonized the inhibitory action of NA on these cells (Segal, 1976). The ineffectiveness of $\mathrm{ACTH}_{4-10}$ on neuronal activity is surprising since this peptide accelerated the rate of hippocampal theta rhythm in rats (Urban and de Wied, 1976), diminished the amplitude of the cortical EPs in these animals (Wolhuis and de Wied, 1976) and affected a number of other macroelectrophysiological measurements in animals and humans (see Sections 3.1 and 3.2 of this review; also Sandman and Kastin, 1981). Iontophoretic structure-activity experiments on neurons in other brain regions are needed in order to identify the site(s) within the ACTH molecule which is (are) responsible for the excitatory properties of $\mathrm{ACTH}$ within the brain.

Systemically injected $\beta$-MSH increased the number of intracellular measured action potentials elicited in $\alpha$-motoneurons in the spinal cord of cats by paired stimuli administered to the dorsal roots. This effect was visible within 2-3 min after the injection and persisted during the rest of the experiment (Krivoy and Zimmerman, 1977). The resting membrane potential, synaptic delay, magnitude and rise time of the excitatory postsynaptic potentials were not altered by the peptide. Unfortunately, other parameters of membrane properties were not examined in this experiment and thus the mechanism and locus of this action of $\beta$-MSH on $\alpha$-motoneurons still remain unclear.

\subsection{EXPERIMENTS IN VITRO}

Henkin et al. (1973) measured the $\mathrm{Na}^{+}$and $\mathrm{K}^{+}$currents in squid giant axons before and after exposure of the axons to $80 \mathrm{IU}$ ACTH. The peptide did not change the ionic current-membrane potential relationship suggesting that ACTH has little or no effect on the basic ionic events that give rise to action potentials. ACTH and $\mathrm{ACTH}_{4-10}$ also did not affect the resting membrane potential (RMP) of rat diaphragm muscle fibers in vitro. This parameter remained unchanged following superfusion of the fibers with $10^{-7} \mathrm{M}$ concentrations of the peptide (Birnberger et al., 1977). The sucrose gap technique (for details see Nishi and Koketsu, 1968; Koketsu, 1969; Wallis et al., 1975) permits quasi-intracellular 
recording from a population of neurons. A shift in the D.C. potential measured across the gap indicates alterations in the RMP of these cells. RMP recorded in this way from frog sympathetic ganglion (SG) neurons showed no appreciable treatment-related fluctuations following perfusion of ganglia for $60 \mathrm{~min}$ with $10^{-6} \mathrm{M} \mathrm{ACTH}_{4-10}$ (Wouters and Van den Bercken, 1979a). An action of peptides on RMP of the brain cells maintained in vitro has not been reported.

Early in vivo experiments have suggested that there were effects of ACTH on neuromuscular transmission (Torda and Wolf, 1952b; Strand et al., 1973/4; Strand and Cayer, 1975; Strand and Smith, 1980). This action has recently been reinvestigated with the isolated phrenic nerve-diaphragm muscle preparation. In neuromuscular preparations, electrical stimulation of the afferent nerve fibers releases acetylcholine from the terminals of these fibers. The acetylcholine interacts with receptors on the adjacent postsynaptic muscular membrane and elicits end-plate potentials (EPPs). The magnitude of the EPPs is related to, amongst others, the amount of acetylcholine released from the nerve terminal. Birnberger et al. (1977) saw the amplitude of EPPs decrease after they added $10^{-7} \mathrm{M}$ $\mathrm{ACTH}$ to the perfusion medium. The same or a stronger $\left(10^{-6} \mathrm{M}\right)$ concentration of $\mathrm{ACTH}_{4-10}$ was without effect on EPPs (Birnberger et al., 1977; Wouters et al., 1979c). In the absence of changes in RMP, the peptide-induced attenuation of the EPPs could have been due to presynaptic suppression by ACTH of acetylcholine release or to interference of the peptide with postsynaptic processes at the receptor site. $\mathrm{ACTH}_{4-10}$ increased the frequency of miniature end-plate potentials (MEPPs) in diaphragm from normal rats and in gastrocnemius muscle fibers isolated from hypophysectomized rats (Birnberger $e t$ al., 1977; Strand and Smith, 1980). The MEPPs are small, randomly occurring fluctuations in the end-plate potential of unstimulated muscle fibers. They are produced by quanta of acetylcholine spontaneously liberated from presynaptic terminals (Katz, 1966). A change in frequency of these potentials therefore always indicates a presynaptic mechanism. Differences in the size of MEPPs could be due to a different size of transmitter quanta, thus having a presynaptic origin. However, the magnitude of MEPPs may also change as a result of postsynaptic processes altering the transmitter-receptor interaction. The magnitude of MEPPs was not affected by peptides (Birnberger et al., 1977; Wouters et al., $1979 \mathrm{c}$ ). Thus, when diminishing the size of EPPs and augmentating the frequency of MEPPs. ACTH and $\mathrm{ACTH}_{4-10}$ were presumably acting on presynaptic terminals.

On electrical stimulation of the afferent fibers fast excitatory postsynaptic potentials (EPSPs) comparable to the muscular EPPs are elicited in neurons of the frog sympathetic ganglion (SG). The fast EPSPs may be followed by slow excitatory postsynaptic potentials (sEPSPs) or by slow inhibitory postsynaptic potentials (sIPSPs) depending upon the type of afferents stimulated (for details see Libet et al., 1968; Weight and Padjen, 1973; Weight, 1974; Nishi, 1976). The fast and slow excitatory postsynaptic potentials are mediated by the same transmitter, acetylcholine. The interaction of acetylcholine with the nicotinic cholinergic synapses elicits the fast EPSPs whereas induction of the sEPSPs requires activation of the atropine-sensitive synapses. It could be inferred from the unaltered magnitude of the fast EPSPs that $\mathrm{ACTH}_{4-10}$ had little effect on the cholinergic transmission mediated by the nicotinic synapse. However, the peptide affected processes at the muscarinic cholinergic synapse. Functioning of the muscarinic synapse is best studied in a ganglion in which transmission through the nicotinic synapse is suppressed with nicotine or D-tubocurarine. In the bullfrog SG superfused with Ringer solution containing one of these blocking agents, a short application of the cholinergic receptor agonist metacholine induced in the SG cells a response consisting of a hyperpolarization-depolarization sequence. Perfusion of the nicotinized ganglia for $60 \mathrm{~min}$ with $10^{-7} \mathrm{M} \mathrm{ACTH}_{4-10}$ in Ringer solution attenuated the hyperpolarization and markedly augmented the depolarization in the metacholine-induced response (see Fig. 3). The alterations in response were usually noticeable 30-60 min after the start of peptide administration and remained for the rest of the experiment. This presumably purely postsynaptic effect of $\mathrm{ACTH}_{4-10}$ could only be partly confirmed by Wouters and Van den Bercken (1979a). They saw a tendency of the acetylcholine-induced response to increase in presence of $\mathrm{ACTH}_{4-10}$ in some of the ganglia 


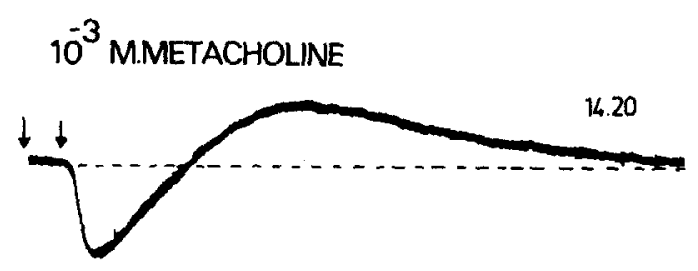

$10^{-7} \mathrm{M} . \mathrm{ACTH}_{4}-10$
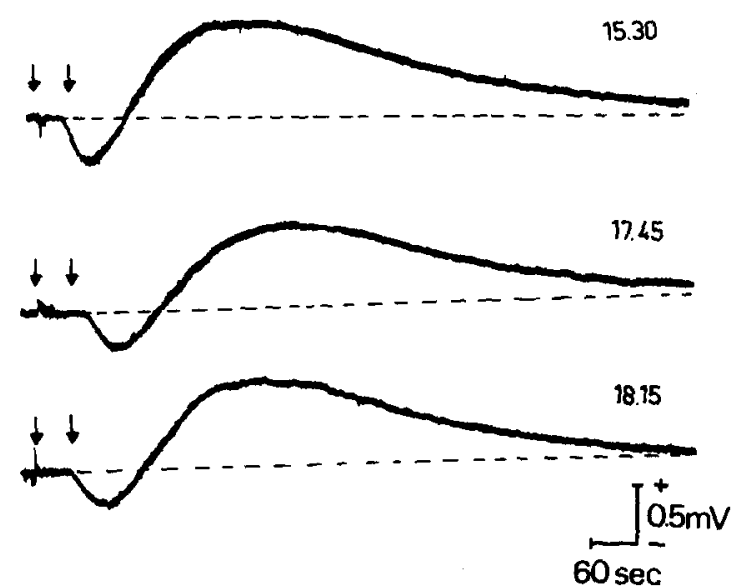

FIG. 3. Effect of $10^{-7} \mathrm{M} \mathrm{ACTH}_{4-10}$ on metacholine response in curarized $(50 \mathrm{mg} / 1$ D-tubocurarine) bullfrog sympathetic ganglia.

only. However, the control depolarizations in their preparations were very small and difficult to measure accurately.

The size of sIPSPs electited in SG by electrical stimuli was markedly enhanced by $\mathrm{ACTH}_{4-10}, 10^{-8} \mathrm{M}$ (Wouters and van den Bercken, 1979a). There is evidence (Libet and Tosaka, 1970) implicating dopamine in the genesis of the sIPSPs. Indeed, a short application of this transmitter elicited a transient hyperpolarization in SG neurons (McAfee and Greengard, 1971). The dopamine-induced hyperpolarization significantly increased in SG exposed to $\mathrm{ACTH}_{4-10}$ (Wouters and Van den Bercken, 1979a). The $\mathrm{ACTH}_{4-10}$ effects on synaptically and on chemically elicited postsynaptic activity followed a very similar time course. This may indicate that the two types of effects have a similar mechanism.

Thus, in vitro, $\mathrm{ACTH}_{4-10}$ acted on both post- and presynaptic sites. Postsynaptically the peptide enhanced the response to neurotransmitters apparently without appreciably altering the properties of the resting membrane. In one preparation, similar amounts of $\mathrm{ACTH}_{4-10}$ augmented the depolarizing and hyperpolarizing responses to agonists for two distinctly different types of synaptic receptors. This nonspecific action, which allows the peptide to alter the input/output relationship in postsynaptic responses mediated by several types of synapses, would have little physiological meaning if all types of synapses were randomly activated. The nonspecific boosting of the postsynaptic response could become significant however, if a specific synaptic input dominated. The response to this input would be selectively enhanced in presence of the peptide. Presynaptically, $\mathrm{ACTH}_{4-10}$ may stimulate the release of neurotransmitter from the nerve terminals. Electrophysiological evidence of this action has so far been obtained only with cholinergic nerve fibers. However, according to biochemical data (for review see Versteeg, 1980) it is quite likely that $\mathrm{ACTH}_{4-10}$ also enhances release from other than cholinergic fibers. This mixed preand postsynaptic action of $\mathrm{ACTH}_{4-10}$ may help in understanding the variety of electrophysiological and behavioral effects (see for review de Wied and Jolles, 1982) of $\mathrm{ACTH}_{4-10}$. 
In addition, there is indirect electrophysiological evidence to suggest that the stimulusinduced release of acetylcholine from the nerve fibers innervating muscles is decreased in presence of ACTH. If this is the case it is another example of the various activities present in the ACTH molecule (for review see de Wied and Jolles, 1982).

\section{EFFECTS OF ENDORPHINS AND ENKEPHALINS ON MACROELECTROPHYSIOLOGICAL MEASUREMENTS}

\subsection{ELECTROENCEPHALOGRAM}

Animals studies with opiate-like peptides derived from the C-terminal portion of the $\beta$-LPH molecule showed both that these peptides are very potent in inducing epileptiform EEG activity when administered directly into the brain and that their effects are mediated through stereospecific opiate receptors. Urca et al. (1977) described alterations which developed in the frontal and occipital EEG following i.c.v. injection of methionine 5 -enkephalin (ME) in rats. Almost immediately after the injection of ME $(200 \mu \mathrm{g})$ the EEG changed into rapidly repeating spikes which evolved into slower, high amplitude sharp waves $(4-6 / \mathrm{sec})$ after $20-30 \mathrm{sec}$. This pattern was often followed by a desynchronized EEG of unusually low amplitude and by a second build-up of the repetitive sharp waves, spikes or wave complexes which lasted for about $20 \mathrm{sec}$. This activity was later replaced by a slow wave activity with spikes and polyspikes or complex waves occurring at a frequency of 5-7/sec. In that study, i.p. injected naloxone neither prevented nor reversed the ME-induced EEG seizures. However, in subsequent experiments (Frenk et al., 1978a) in which $100 \mu \mathrm{g}$ leucine ${ }^{5}$-enkephalin (LE) was used, pretreatment of rats with naloxone greatly attenuated or blocked the development of the abnormal EEG activity.

The electroencephalographic changes induced by i.c.v. D-Ala ${ }^{2}$-ME (DAME) amide closely resembled those seen after i.c.v. administered morphine. The slow waves with bursts of high voltage spikes that occurred in the frontal and occipital EEGs following microinjections of $10 \mu \mathrm{g}$ DAME amide could be mimicked with $5 \mu \mathrm{g}$ of the opiate alkaloid. Morphine $10 \mu \mathrm{g}$ converted the EEG patterns into the same high voltage spike continuum as did $20 \mu \mathrm{g}$ of the peptide. Naloxone prevented the development of the peptide- and morphine-elicited EEG patterns (Tortella et al., 1978). Microinjection of ME or LE into the dorsomedial thalamic nucleus, but not into the periaqueductal matter triggered epileptic-like activity similar to that seen following i.c.v. administration of these peptides (Frenk et al., 1978b)

When centrally administered, $\beta$-endorphin $\left(\beta \mathrm{E}, \beta-\mathrm{LPH}_{61-91}\right)$ appeared to induce EEG and behavioral seizures more potently even than the enkephalins. La Bella et al. (1978) showed that $2 \mu \mathrm{g}$ of this peptide injected into one of the lateral brain ventricles could convert the cortical EEG of rats into spike activity. In rabbits, clear paroxysmal high voltage discharges were observed only if a $60 \mu \mathrm{mol}$ solution of $\beta \mathrm{E}$ in artificial cerebrospinal fluid was injected into the lateral ventricles. Administration of the peptide in the third ventricle only slowed down the dominant background activity from $6-7 \mathrm{~Hz}$ to $3-5 \mathrm{~Hz}$ and markedly decreased the average power of the signal. These naloxone reversible effects were strongest $10-20 \mathrm{~min}$ after the injection and the EEG returned to control levels within 90 min (Firemark and Weitzman, 1979).

There is strong evidence to suggest that the epileptiform effects of the opioid peptides on the EEG, which are mediated by the opiate receptors, originate in the forebrain limbic structures and the hippocampus in particular. The marked paroxysmal activity with epileptic spikes seen in the cortical EEG shortly after a 3-5 $\mu \mathrm{M}$ Ringer solution of synthetic procine or human $\beta E$ was i.c.v. injected, developed first and reached its highest amplitude in subcortical structures like the septum, medial preoptic area, central amygdala and the medial dorsal thalamus before it appeared on leads from the somatosensory motor cortices (Henriksen et al., 1978). In the encephale isolé cat, even $0.2 \mu \mathrm{g}$ of LE administered directly into the hippocampus resulted in epileptiform discharges lasting several min, followed by a flat EEG. The hippocampus of rats anesthetized with urethane showed seizures only after 
$5 \mu \mathrm{g}$ of the peptide had been given (Elazar et al., 1978). The great susceptibility of hippocampal tissue to epileptic discharges following exposure to opiate-like peptides was elegantly demonstrated by Taylor et al. (1979) in isolated hippocampus in vivo. These authors transplanted the embryonal regio superior (CA1 and CA2) of the fetal rat hippocampus into the anterior eye chamber of an adult rat. The transplants were allowed to develop for at least two months in oculo. For the experiments, a recording chamber was formed by means of a plastic ring around the transplant. Superfusion of the thus isolated hippocampus with $10^{-7} \mathrm{M} \beta \mathrm{E}$ resulted in naloxone reversible epileptic discharges.

Blockade of the inhibitory GABA-ergic neurotransmission is perhaps the principal mechanism for induction of hippocampal seizure activity by opiate-like peptides (Nicoll et al., 1980; Dingledine, 1981). However, the blockade of GABA-ergic transmission is presumably only one of the many effects of opiate-like peptides on brain processes. Dopamine, acetylcholine, serotonin and even vasopressin release were also affected by these peptides (Versteeg, 1980; Iversen et al., 1980; Bickell and Leng, 1982).

In a combined behavioral and electrophysiological study, de Wied et al. (1978a) examined the effects of i.c.v. administered $\beta \mathrm{E}$ on the extinction of pole jumping avoidance behavior and on the frequency of hippocampal theta activity in rats during PS. When $20-30 \mathrm{ng}$ of the peptide was injected the extinction of pole jumping was delayed and the occurrence of high theta frequencies in hippocampal EEG activity was increased. There were no behavioral or electroencephalographic signs of a seizure type of activity in the peptide-treated animals. Met ${ }^{5}$-enkephalin $(20 \mathrm{ng})$ also given i.c.v. did not affect hippocampal activity. The $\beta \mathrm{E}$-induced frequency increase in hippocampal theta rhythm was also reported by Henriksen et al. (1978). Morphine suppressed the occurrence of theta rhythm (Linseman and Grupp, 1980; Klemm et al., 1977) suggesting that the effect of $\beta \mathrm{E}$ on theta rhythm was presumably associated with an activity other than the opiate-like activity of $\beta \mathrm{E}$. The non-opiate activity of $\beta \mathrm{E}$ was recently disclosed in behavioral experiments with the pole jumping avoidance response. In these studies $\beta E, \beta-\mathrm{LPH}_{61-69}$ and $\alpha \mathrm{E}\left(\beta-\mathrm{LPH}_{61-76}\right)$ all delayed extinction of the pole jumping avoidance response. Pretreatment of rats with naloxone in doses which prevent $\beta E$-induced analgesia did not interfere with the effect of $\alpha \mathrm{E}$ on the extinction of the avoidance response (de Wied et al., 1978a). Another peptide, $\gamma \mathrm{E}\left(\beta-\mathrm{LPH}_{61-77}\right)$ had the opposite effect and facilitated the extinction of the pole jumping avoidance response. Removal of the $N$-terminal amino acid tyrosine from $\gamma \mathrm{E}$ and $\alpha \mathrm{E}$ yielded the peptides (Des-Tyr $\left.{ }^{1}\right)-\gamma \mathrm{E}\left(\beta-\mathrm{LPH}_{62-77}\right)$ and $\left(\mathrm{Des}^{-} \mathrm{Tyr}^{\mathrm{l}}\right)-\alpha \mathrm{E}\left(\beta-\mathrm{LPH}_{62-76}\right)$ that were devoid of most of the opiate-like analgesic activities. These peptides however retained the full activity of the original peptides in the avoidance procedures (de Wied et al., 1978a; Bohus et al., 1980).

The rat pituitary and rat brain (Loeber et al., 1979; Verhoef et al., 1980, 1982) contain DT $\gamma \mathrm{E}$ and DT $\alpha$ E. Depending on the $\mathrm{pH}, \mathrm{DT} \gamma \mathrm{E}$ and DT $\alpha \mathrm{E}$ could be obtained preferentially in vitro from the $\beta \mathrm{E}$ molecule by exposure of the molecule to enzymes associated with an enriched synaptosomal plasma membrane fraction (Burbach et al., 1980). It was therefore suggested that two peptides formed from the same parent molecule may have different functions in the brain. Recently, we have studied the effects of DT $\alpha E$ and DT $\gamma \mathrm{E}$ on the spontaneous EEG of the lateral septal complex (LSC) and frontal cortex of the rat (Urban and de Wied, 1982). As the activity of DT $\gamma E$ in various behavioral tests resembled that of haloperidol (de Wied et al., 1978b; Kovacs and de Wied, 1978; Van Ree et al., 1980) this neuroleptic drug was also included in the study. The rats were injected on two subsequent days either with placebo (saline solution) or with one of the compounds to be tested. EEG activity was quantified by power spectral analysis. The effects of treatment were evaluated by computing the differences between average spectra of corresponding periods in the placebo and the peptide or haloperidol treatment sessions and comparing these differences in the ' $t$ '-test for paired values. The ' $t$ ' profiles so obtained showed a significant increase in activity of the $5 \mathrm{~Hz}$ band following $2 \mu \mathrm{g}$ of DT $\alpha \mathrm{E}$. Treatment with $10 \mu \mathrm{g}$ of DT $\gamma \mathrm{E}$ had the opposite effect and led to a decrease in the amount of activity in this band. In addition, DT $\alpha \mathrm{E}$ promoted the production of $15-20 \mathrm{~Hz}$ activity while DT $\gamma \mathrm{E}$ decreased the amount of $20-30 \mathrm{~Hz}$ activity. EEG activity exhibited a marked 
variability which persisted throughout the recording sessions following administration of the peptides. Haloperidol markedly decreased the proportion of $10-15 \mathrm{~Hz}$ activity. The alterations in EEG of the frontal cortex followed those in LSC but were less pronounced. The differences in the time course and frequency bands affected suggest that the effects of peptides and haloperidol on the EEG activity of LSC are not mediated by the same mechanisms. However, the data support the notion that two closely related neuropeptides derived from the same molecule may have different functions in the brain.

There have been only few studies published concerning the effect of opiate-like peptides on the human EEG. In one of these studies (Von Graffenried et al., 1978), 12 healthy volunteers were injected (i.m.) with $0.1-2 \mathrm{mg}$ of a synthetic analog of $\mathrm{ME}\left(\mathrm{FK}_{33-824}\right)$. Spectral analysis of the spontaneous EEG recorded following the treatment revealed a slowing down of the alpha-waves, an increase of almost $50 \%$ in beta activity and an increase in the total power of the signal. The increase in alpha band activity was detectable by visual inspection of the EEG records. This pattern was most pronounced $2-4 \mathrm{hr}$ after administration of the peptide. Nalorphine injected 90 min after $F_{33-824}$ failed to interfere with the peptide-induced changes. In another study on 20 volunteers, $0.5 \mathrm{mg} \mathrm{FK}_{33-824}$ led to a naloxone reversible increase in alpha and beta band activities, perhaps as a result of hypersynchronized and spindling activities (Krebs and Roubicek, 1979). Angst et al. (1979) treated 6 female patients with $10 \mathrm{mg}$ of synthetic $\beta$-endorphin given in a single i.v. injection. Visual examination of the spontaneous EEG recorded from the temporoparietal and parieto-occipital leads showed no obvious alteration. However, spectral analysis of the data revealed an increase in power of the alpha $(7.5-12.5 \mathrm{~Hz})$ and beta $(12.5-22.5 \mathrm{~Hz})$ bands in the first $60 \mathrm{~min}$ after injection. This increase was later followed by a decrease of activity in these bands. Interestingly, none of these studies reported any development of the epileptoid EEG waves typical of the opiate-like activity of peptides.

\subsection{EVOKed Potentials}

To our knowledge no studies have been published on the effects of EPs of peptides derived from the $\beta$-LPH molecule.

\subsection{Multiple-Unit Activity}

There is only one study (Urca et al., 1977) which demonstrated an opiate-like effect of ME on MUA. In this study, the i.c.v. administration of a large $(200 \mu \mathrm{g})$ dose of ME increased the frequency of action potentials in MUA records from the periaqueductal central grey in the same way as did $30 \mu \mathrm{g}$ of morphine. The MUA increase could be prevented or compleiely reversed by naloxone.

\section{EFFECTS OF ENKEPHALINS AND ENDORPHINS ON MICROELECTROPHYSIOLOGICAL MEASUREMENTS}

\subsection{Single Neurons $I_{N}$ VIVO}

The analgesic action of morphine and of other opiate alkaloids has been attributed in part to a selective depression by opiates of transmission between the primary afferent fibers and the nociceptive dorsal horn (DH) neurons (Henry and Newman, 1974; Calvillo et al., 1974). It therefore seemed logical to hypothesize that the analgesia elicited by enkephalins and endorphins may have a similar mechanism, namely suppression of the pain-induced activity in the DH neurons. Such a hypothesis was supported by the finding of a high concentration of the stereospecific opiate receptors in the substantia gelatinosa, the site of terminal branches of the sensory afferents (Lamotte et al., 1976; Pert et al., 1975; Atweh and Kuhor, 1977a). In addition, histochemical experiments revealed the presence of immunoreactive enkephalin-like peptides in many axons and cell bodies in this region (Elde et al., 1976; Hökfelt et al., 1977a,b) suggesting a physiological role for enkephalins in the transmission of pain stimuli. The earlier iontophoretic experiments indeed showed that ME and LE, similarly to morphine, levorphanol but not dextrophan, an inactive D-enantiomer of levorphanol, inhibit spontaneous or stimulated activity in most of the DH neurons 
(Duggan et al., 1976; Zieglgänsberger and Bayerl, 1976b; Duggan and Headley, 1978). The depressant action of opioid peptides, like that of opiate alkaloids, could in many cases be reversibly abolished by iontophoretic or systemic administration of naloxone indicating the involvement of stereospecific opiate receptors in the response of DH to enkephalins. The caudal trigeminal nuclus is functionally equivalent to the DH of the spinal cord. Here too, the locally applied $\mathrm{ME}$ or $\beta-\mathrm{E}$ caused a naloxone reversible depression in spontaneous firing rate and decreased the trigeminal nucleus neurons to pain-inducing stimuli (Andersen et al., 1978; Henry, 1978). Subsequent experiments revealed the more general character of the depressant action exerted by opioid peptides on mammalian neurons (see Table 1). Thus, met-enkephalins and endorphins diminished the spontaneous and stimulus-induced neuronal responses not only in the medulla oblongata, brain stem and thalamus, i.e. in structures transmitting the pain stimuli to the higher brain centra, but also in structures like the hypothalamus, striatum and frontal cortex that are remote from the pathways mediating the noxious stimuli.

In contrast to the DH cells, the spinal cord interneurons identified by electrical stimulation of ventral roots as the Renshaw cells, were excited by ME and morphine. In addition, ME decreased the reactivity to acetylcholine of these presumably cholinoceptive

TABLE 1.

\begin{tabular}{|c|c|c|c|c|c|}
\hline $\begin{array}{l}\text { Animal/ } \\
\text { Structure }\end{array}$ & Type of Neuron & Peptide & Dominant Effect & $\begin{array}{l}\text { Antagonist } \\
\text { Reversible }\end{array}$ & Reference \\
\hline $\begin{array}{l}\text { Cat } \\
\text { spinal cord }\end{array}$ & $\begin{array}{l}\text { nociceptive and } \\
\text { non-nociceptive } \\
\text { neurons }\end{array}$ & $\begin{array}{l}\text { ME } \\
\text { ME-amide }\end{array}$ & $\begin{array}{l}\text { applied to SUGEL } \\
\downarrow \text { noxious S-IA } \\
\text { little effect on } \\
\text { non-noxious S-IA }\end{array}$ & + & Duggan et al., 1976 \\
\hline $\begin{array}{l}\text { Cat } \\
\text { spinal cord }\end{array}$ & DH neurons & $\begin{array}{l}\text { ME } \\
\text { ME-amide }\end{array}$ & $\begin{array}{l}\text { near cell bodies } \\
\downarrow \text { SA and S-IA } \\
\text { in SUGEL } \\
\downarrow \text { SA } \\
\downarrow \text { noxious S-IA } \\
\text { little or no effect } \\
\text { on non-noxious S-IA }\end{array}$ & + & Duggan et al., 1977 \\
\hline $\begin{array}{l}\text { Cat } \\
\text { spinal cord }\end{array}$ & DH neurons & $\begin{array}{l}\text { ME } \\
\text { LE }\end{array}$ & $\begin{array}{l}\text { no effect on SA } \\
\text { S-IA }\end{array}$ & & Davies and Dray, 1978 \\
\hline $\begin{array}{l}\text { Cat } \\
\text { spinal cord }\end{array}$ & $\mathrm{DH}$ neurons & $\begin{array}{l}\text { D-Ala }{ }^{2} \\
\text { LE-amide }\end{array}$ & $\begin{array}{l}\downarrow \text { noxious S-IA } \\
\text { no effect on non- } \\
\text { noxious S-IA }\end{array}$ & + & Davies and Dray, 1980 \\
\hline $\begin{array}{l}\text { Cat } \\
\text { spinal cord }\end{array}$ & DH neurons & ME-amide & $\begin{array}{l}\text { applied to SUGEL } \\
\downarrow \text { noxious S-Ia }\end{array}$ & + & $\begin{array}{l}\text { Duggan and Headley, } \\
1978\end{array}$ \\
\hline $\begin{array}{l}\text { Cat } \\
\text { spinal cord }\end{array}$ & $\begin{array}{l}\text { nociceptive and } \\
\text { other neurons }\end{array}$ & ME & $\begin{array}{l}\downarrow \text { SA } \\
\text { \ S-IA } \\
\downarrow \text { glutamate-IA } \\
\downarrow \text { Substance P-IA }\end{array}$ & + & $\begin{array}{l}\text { Zieglgänsberger and } \\
\text { Tulloch, 1979a,b. }\end{array}$ \\
\hline $\begin{array}{l}\text { Cat } \\
\text { spinal cord }\end{array}$ & $\begin{array}{l}\text { nociceptive } \\
\text { neurons }\end{array}$ & ME & $\downarrow$ noxious S-IA & not tested & $\begin{array}{l}\text { Randic and Miletic, } \\
1978\end{array}$ \\
\hline $\begin{array}{l}\text { Cat } \\
\text { spinal cord }\end{array}$ & $\begin{array}{l}\text { nociceptive } \\
\text { neurons }\end{array}$ & $\beta \mathrm{E}$ & $\downarrow$ noxious S-IA & not tested & Henry, 1978 \\
\hline $\begin{array}{l}\text { Cat } \\
\text { spinal cord }\end{array}$ & Renshaw cells & $\begin{array}{l}\mathrm{ME} \\
\mathrm{LE}\end{array}$ & $\uparrow \mathrm{SA}$ & + & $\begin{array}{l}\text { Davies and Dray, } \\
\text { 1976a,b }\end{array}$ \\
\hline $\begin{array}{l}\text { Cat } \\
\text { spinal cord }\end{array}$ & Renshaw cells & $\begin{array}{l}\text { ME } \\
\mathrm{LE}\end{array}$ & $\uparrow \mathrm{SA}$ & + & Davies and Dray, 1978 \\
\hline $\begin{array}{l}\text { Cat } \\
\text { spinal cord }\end{array}$ & DH neurons & ME & $\downarrow \mathbf{S A}$ & not tested & $\begin{array}{l}\text { Miletic and Randic, } \\
1982\end{array}$ \\
\hline $\begin{array}{l}\text { Cat } \\
\text { caudal trigeminal } \\
\text { nucleus }\end{array}$ & $\begin{array}{l}\text { nociceptive and } \\
\text { non-nociceptive } \\
\text { neurons }\end{array}$ & ME & $\begin{array}{l}\uparrow S A \text { in nociceptive } \\
\text { neurons } \\
\downarrow \text { noxious S-IA in } \\
\text { nociceptive neurons } \\
\text { little or no effect } \\
\text { on non-nociceptive } \\
\text { cells }\end{array}$ & + & Andersen et al., 1978 \\
\hline $\begin{array}{l}\text { Rat medulla } \\
\text { oblongata }\end{array}$ & $\begin{array}{l}\text { unidentified } \\
\text { neurons }\end{array}$ & ME & $\downarrow$ SA & not tested & Hill et al., 1976. \\
\hline
\end{tabular}


TABLE 1 cont

\begin{tabular}{|c|c|c|c|c|c|}
\hline $\begin{array}{c}\text { Animal/ } \\
\text { Structure } \\
\end{array}$ & Type of Neuron & Peptide & Dominant Effect & $\begin{array}{l}\text { Antagonist } \\
\text { Reversible }\end{array}$ & Reference \\
\hline $\begin{array}{l}\text { Rat medulla } \\
\text { oblongata }\end{array}$ & $\begin{array}{l}\text { respiratory } \\
\text { neurons }\end{array}$ & ME & $\downarrow$ SA & + & $\begin{array}{l}\text { Denavit-Saubié et al., } \\
1978\end{array}$ \\
\hline $\begin{array}{l}\text { Cat } \\
\text { brain stem }\end{array}$ & $\begin{array}{l}\text { n. reticularis } \\
\text { giganto-cellularis, } \\
\text { n. pontis caudalis } \\
\text { neurons }\end{array}$ & $\begin{array}{l}\mathrm{ME} \\
\mathrm{LE} \\
\beta \mathrm{E}\end{array}$ & $\begin{array}{l}\downarrow \text { SA } \\
\downarrow \text { Homocysteate-IA } \\
\downarrow \text { noxious S-IA }\end{array}$ & - & $\begin{array}{l}\text { Gent and Wolstencroft, } \\
\text { 1976a,b; Gentet al., } 1977\end{array}$ \\
\hline $\begin{array}{l}\text { Cat } \\
\text { brain stem }\end{array}$ & $\begin{array}{l}\text { n. reticularis } \\
\text { giganto cellularis, } \\
\text { n. pontic caudalis, } \\
\text { n. raphe bulbaris } \\
\text { and periaqueducta } \\
\text { gray nociceptive } \\
\text { neurons }\end{array}$ & $\begin{array}{l}\mathrm{ME} \\
\mathrm{LE} \\
\alpha \mathrm{E} \\
\beta \mathrm{E} \\
1\end{array}$ & $\begin{array}{l}\downarrow \text { SA } \\
\downarrow \text { noxious SA }\end{array}$ & - & $\begin{array}{l}\text { Wolstencroft et al., } \\
1978\end{array}$ \\
\hline $\begin{array}{l}\text { Cat } \\
\text { brain stem }\end{array}$ & $\begin{array}{l}\text { unidentified } \\
\text { neurons }\end{array}$ & ME & $\downarrow \mathrm{SA}$ & + & Davies and Dray, 1978 \\
\hline $\begin{array}{l}\text { Rat } \\
\text { brain stem }\end{array}$ & $\begin{array}{l}\text { unidentified } \\
\text { neurons }\end{array}$ & ME & $\begin{array}{l}\downarrow \text { SA } \\
\uparrow \text { SA }\end{array}$ & \pm & Bradley et al., 1976 \\
\hline $\begin{array}{l}\text { Rat } \\
\text { brain stem }\end{array}$ & $\begin{array}{l}\text { n. reticularis } \\
\text { giganto-cellularis } \\
\text { neurons }\end{array}$ & $\begin{array}{l}\text { ME } \\
\text { LE } \\
\text { D-Ala }{ }^{2}-\mathrm{ME}- \\
\text { amide } \\
\text { D-Ala }{ }^{2}-\mathrm{D}- \\
\text { Leu }^{5}-\mathrm{E}\end{array}$ & $\downarrow$ SA & + & Bradley et al., 1978a,b \\
\hline $\begin{array}{l}\text { Rat } \\
\text { brain stem }\end{array}$ & $\begin{array}{l}\text { n. reticularis } \\
\text { giganto-cellularis } \\
\text { and } n \text {. pontis }\end{array}$ & $\begin{array}{l}\mathrm{ME} \\
\beta \mathrm{E}\end{array}$ & $\downarrow \mathbf{S A}$ & + & $\begin{array}{l}\text { Bradley and Bramwell, } \\
1977\end{array}$ \\
\hline $\begin{array}{l}\text { Rat } \\
\text { brain stem }\end{array}$ & $\begin{array}{l}\text { n. reticularis } \\
\text { lateralis }\end{array}$ & $\begin{array}{l}\mathrm{ME} \\
\mathrm{LE} \\
\alpha \mathrm{E} \\
\beta \mathrm{E}\end{array}$ & $\downarrow \mathbf{S A}$ & + & $\begin{array}{l}\text { Nicoll et al., } 1977 \\
\text { Siggins et al., } 1978\end{array}$ \\
\hline $\begin{array}{l}\text { Rat } \\
\text { brain stem }\end{array}$ & $\begin{array}{l}\text { noociceptive } \\
\text { neurons }\end{array}$ & ME & $\downarrow$ noxious S-IA & + & $\begin{array}{l}\text { Hosford and Haigler, } \\
1980\end{array}$ \\
\hline $\begin{array}{l}\text { Rat } \\
\text { brain stem }\end{array}$ & $\begin{array}{l}\text { periaqueductal } \\
\text { gray neurons }\end{array}$ & ME & $\downarrow \mathrm{SA}$ & + & $\begin{array}{l}\text { Frederikson and Norris, } \\
1976\end{array}$ \\
\hline $\begin{array}{l}\text { Rat } \\
\text { brain stem } \\
\text { neurons }\end{array}$ & locus coeruleus & ME & $\downarrow \mathrm{SA}$ & + & Young et al., 1977 \\
\hline $\begin{array}{l}\text { Rat } \\
\text { brain stem }\end{array}$ & $\begin{array}{l}\text { locus coerulus } \\
\text { neurons }\end{array}$ & ME & $\downarrow$ SA & not tested & $\begin{array}{l}\text { Guyenet and } \\
\text { Aghajanian, } 1977\end{array}$ \\
\hline $\begin{array}{l}\text { Rat } \\
\text { thalamus }\end{array}$ & $\begin{array}{l}\text { nociceptive } \\
\text { neurons }\end{array}$ & ME & $\downarrow$ noxious S-IA & not tested & Hill et al., 1976 \\
\hline $\begin{array}{l}\text { Rat } \\
\text { thalamus }\end{array}$ & $\begin{array}{l}\text { nociceptive } \\
\text { neurons }\end{array}$ & ME & $\downarrow$ noxious S-IA & $-(+)$ & Hill and Pepper, 1976 \\
\hline $\begin{array}{l}\text { Rat } \\
\text { thalamus }\end{array}$ & $\begin{array}{l}\text { nociceptive } \\
\text { neurons }\end{array}$ & $\begin{array}{l}\text { D-Ala }{ }^{2}-\mathrm{D}- \\
\text { Leu }^{5}-\mathrm{E} \\
\text { D-Tyr } \\
\text { Ala }-\mathrm{D}-\mathrm{D}-\mathrm{Leu}{ }^{5}- \\
\text { E }\end{array}$ & $\begin{array}{l}\downarrow \text { noxious S-IA } \\
\text { no effect }\end{array}$ & + & $\begin{array}{l}\text { Hill and Pepper, } \\
\text { 1978a,b }\end{array}$ \\
\hline $\begin{array}{l}\text { Rat } \\
\text { thalamus }\end{array}$ & $\begin{array}{l}\text { unidentified } \\
\text { neurons }\end{array}$ & $\begin{array}{l}\mathrm{ME} \\
\mathrm{LE} \\
\alpha \mathrm{E} \\
\beta \mathrm{E}\end{array}$ & $\downarrow$ SA & + & $\begin{array}{l}\text { Nicoll et al., } 1977 \\
\text { Siggins } \text { et al., } 1978\end{array}$ \\
\hline $\begin{array}{l}\text { Rat } \\
\text { caudate nucleus }\end{array}$ & $\begin{array}{l}\text { unidentified } \\
\text { neurons }\end{array}$ & $\begin{array}{l}\text { ME } \\
\mathrm{LE} \\
\alpha \mathrm{E} \\
\beta E\end{array}$ & $\downarrow \mathrm{SA}$ & + & Nicoll et al., 1977 \\
\hline $\begin{array}{l}\text { Rat } \\
\text { caudate nucleus }\end{array}$ & $\begin{array}{l}\text { unidentified } \\
\text { neurons }\end{array}$ & ME & $\downarrow \mathbf{S A}$ & + & $\begin{array}{l}\text { Frederikson and Norris, } \\
\quad 1976\end{array}$ \\
\hline $\begin{array}{l}\text { Rat } \\
\text { striatum }\end{array}$ & $\begin{array}{l}\text { unidentified } \\
\text { neurons }\end{array}$ & ME & $\downarrow \mathrm{SA}$ & + & Fry et al., 1978 \\
\hline
\end{tabular}

DH, dorsal horn; SA, spontaneous activity; S-IA, stimulus-induced activity; SUGEL, substansia gelatinosa; $\uparrow$, increase; $\downarrow$, decrease. 
neurons and in that action the peptide differed from morphine which enhanced the acetylcholine-induced excitation of the Renshaw cells (Davis and Dray, 1976a,b). The hippocampal pyramidal neurons were another kind of cells which was repeatedly excited by opioid peptides (Nicoll et al., 1977). Recently, Zieglgänsberger et al. (1979) obtained simultaneous recordings from a hippocampal pyramidal neuron and from another cell that could have been an interneuron because the increased firing in the interneuron was time-related to inhibition of the pyramidal cell. $\beta \mathrm{E}$ applied by pressure ejection in the vicinity of these cells markedly attenuated the spontaneous activity of the interneuron and at the same time induced firing in the pyramidal cell. Iontophoretically released $\mathrm{Mg}^{2+}$ or bicuculine suppressed the $\beta \mathrm{E}$-induced excitation, suggesting that in exciting the pyramidal cells, the opioid peptides presumably acted upon the inhibitory interneurons and suppressed the activity in these neurons.

Some amino acids, e.g. L-glutamate or aspartate elicit powerful excitation in most of the mammalian neurons (Curtis et al., 1972). These amino acids are therefore frequently employed as a tool to excite the silent or the slowly spontaneously firing neurons particularly in those microiontophoretic experiments in which the actions of presumed inhibitory compounds on single neurons in vivo are being examined.

ME-amide, $N$-acetyl-D-Ala ${ }^{2}$-Lys-ME, ME, D-Ala ${ }^{2}$ ME or $\beta E$ markedly attenuated the neuronal responses of neurons to glutamate and aspartate (Frederikson and Noris, 1976; Zieglgänsberger et al., 1976; Segal 1977; Zieglgänsberger and Tulloch, 1979a,b). In addition, enkephalin and analogs also appeared to depress the excitation of the spinal cord and neocortical neurons by acetylcholine (Davies and Dray, 1976a; Segal, 1977; Palmer et al., 1978) just as they diminished the increase in firing rate elicited in some spinal cord cells by iotophoretic application of Substance P (Zieglgänsberger and Tulloch, 1979b). Unfortunately, we do not know whether the opioid peptides can elicit all these different effects in the same neurons or whether they exert different effects in different neurons. different effects in different neurons.

Many effects of enkephalins and endorphins on single neurons in vivo could be prevented or reversed by administering the stereospecific opiate receptor antagonist naloxone (see Table 1) and thus they are presumably mediated by some kind of opiate receptor. Hosford and Haigler (1980) compared the effect exerted by ME and morphine on the stimulusinduced response in the same mesencephalic reticular neuron of rats. Both compounds affected the response of these neurons in one of the three following ways. ME but not morphine blocked the stimulus-induced excitation, morphine and not ME abolished the response, both morphine and ME suppressed the firing evoked in the reticular neurons by nociceptive stimulation. Naloxone either given systemically or applied iontophoresis antagonised the action of ME as readily as it blocked the effects of opiate alkaloids. This suggests that at least two kinds of stereospecific opiate receptors may exist on the same neuron. The existence of different ( $\mu$ and $\delta$ ) opiate receptors in the spinal cord and brain had been expected from receptor binding studies (Lord et al., 1977; Fields et al., 1980). Electrophysiological evidence that $\mu$-and $\delta$-types of opiate receptors coexist on the same anterior neurons has recently been provided by Egan and North (1981). The functional significance of multiple opiate receptors on the same cells is not known.

Naloxone was not always equally effective in antagonizing the action of opioid peptides on single neurons in vivo. The antagonist given i.v. abolished the ME-induced decrease in reactivity of the thalamic neurons to pain stimuli in only 2 of 8 cells tested (Hill et al., 1976). Gent and Wolstencroft $(1976 \mathrm{a}, \mathrm{b})$ were unsuccessful in antagonizing the inhibitory action of enkephalins on the raphe, periaqueductal gray and brain stem neurons in cats. Fry et al. (1979) reported that most of the excitatory and inhibitory responses of hippocampal neurons to iontophoretically applied ME were resistant to pretreatment with naloxone. Thus, it cannot be excluded that the opioid peptides may also have some action other than the stereospecific actions on single cells.

\subsection{EXPERIMENTS IN VITRO}

The significant amount of stereospecific opiate receptors that autoradiographic and 
other methods detected in the substantia gelatinosa of the spinal cord, or elsewhere within the brain, appears to be located on the presynaptic fibers (Atweh et al., 1978; Lamotte et al., 1976; Fields et al., 1980). It could therefore be expected that opioid peptides and opiate alkaloids act at least partly at the presynaptic sites. Indeed, enkephalins and their analogs significantly reduced the amounts of acetylcholine, noradrenaline, dopamine or Substance $\mathrm{P}$ released from various neural tissues by $\mathrm{K}^{+}$or by electrical stimuli (Kosterlitz and Hughes, 1975; Waterfield and Kosterlitz, 1975; Loh et al., 1976; Jessel and Iversen, 1977; Subramanian et al., 1977; Waterfield et al., 1977; Mudge et al., 1979a,b). By separating the pars nervosa/pars intermedia from the hypothalamus of rats, Iversen and his co-workers (Iversen et al., 1980) obtained a preparation which contained only the neurosecretory axons and their terminals but not the cell bodies of the hypothalamic neurosecretory neurons, the site of synthesis of vasopressin. It had been shown previously with this preparation that electrical stimuli delivered to the distal part of the pituitary stalk released vasopressin into the incubating medium (Dreifuss et al., 1971). Incubating the posterior pituitary fragments with D-Ala ${ }^{2}-\mathrm{D}-\mathrm{Leu}^{5}$-enkephalin (DADL) led to a marked depression of the electrically elicited release of vasopressin. The efflux of luteinizing hormone-releasing factor and somatostatin from hypothalamic slices challenged by $\mathrm{K}^{+}$ could also be suppressed by opioid peptides (Drouva et al., 1981). The opiate receptor agonist etorphine decreased the amplitude of the excitatory postsynaptic potentials elicited in cultured murine spinal cord cells. Statistical analysis of these potentials indicated that the release of transmitter mediating the EPSPs had been suppressed (MacDonald and Nelson, 1978). In other experiments on cats (Carstens et al.,1979), systemically administered morphine elevated the threshold for antidromic excitation of the small diameter C-primary afferents. Thus, the presynaptic depression of neurotransmitter and hormone release may be an important mechanism in the action of opioid peptides on brain and neuroendocrine processes.

The spinal cord primary afferents are some of the few presynaptic fibers that are accessible to electrophysiological measurements. Stimulating the ventral or the adjacent dorsal roots elicits depolarization of these afferents that can be measured in the proximal ends of the dorsal roots (DR) as a transient voltage deflection called dorsal root potential (DRP). Functionally, the depolarization of primary afferents indicates the presynaptic inhibition of transmitter release from the primary afferents and the magnitude of the DRP reflects the amount of this inhibition (for review see Schmidt, 1971). Superfusion of the isolated frog spinal cord with Ringer solution containing $10 \mu \mathrm{M}$ of D-Ala ${ }^{2}-\mathrm{ME}$ (DALA) almost completely abolished the DRPs in response to ventral roots stimulation. The depression by opioid peptides of the DRPs was also found by others in rats and cats (Sastry, 1978; Pomeranz and Gurevich, 1979; Suze and Jesell, 1980). According to the current concept (Schmidt, 1971; Burke and Rudomin, 1977), the presynaptic inhibition in the primary afferents is caused by depolarization of these afferents with GABA released synaptically in the vicinity of these terminals. A decrease in magnitude of DRPs would therefore indicate a diminished release of GABA or attenuated effect of the inhibitory transmitter on the primary afferents. The former seems more likely since ME increased rather than decreased the GABA-induced depolarization in the DR ganglion cells (Williams and Zieglgänsberger, 1981). The slow IPSP elicited transsynaptically in the frog SG neurons markedly decreased in magnitude during perfusion of SG with $10^{-7} \mathrm{M} \mathrm{ME}$ or D-Ala ${ }^{2}-\mathrm{ME}$ (Wouters and van den Bercken, 1979b, 1980). This effect was presumably also a presynaptic one as the postsynaptic hyperpolarization of the neurons in response to the presumed mediator of the IPLSPs was little affected by peptides.

During sucrose gap measurements of the DRPs in frog spinal cord, Nicoll and collaborators (Nicoll et al., 1980) noticed a small but consistent hyperpolarization of the primary afferent fibers exposed to DALA. The peptide-elicited hyperpolarization could not be abolished by adding the synaptic transmission blocking agents tetrodotoxin (TTX) or $\mathrm{Mg}^{2+}$ into the incubating medium and thus it must have reflected a direct action of DALA on the fibers. Interestingly, the dorsal root ganglionic neurons often used as model for the presynaptic membranes of the primary afferents were not hyperpolarized by enkephalins 
and their analogs (Mudge et al., 1979a,b; Williams and Zieglgänsberger, 1981). It is not clear how the hyperpolarization of terminals could lead to decreased transmitter release from these terminals. The model of presynaptic inhibition in primary afferents assumes that the GABA-induced depolarization of afferent fibers will diminish the amplitude of arriving action potentials by shunting the membrane currents and thus prevent depolarization of the terminals to the extent necessary for normal functioning of the release mechanisms. From this it follows that hyperpolarizing the presynaptic fibers will increase rather than decrease the amplitude of an action potential invading the terminal and this should increase the amounts of mediator released from the terminal. The hyperpolarization associated with increased $\mathrm{Cl}^{-}$conductance (Kawai and Niwa, 1978) could however bring about the same shunting effects as depolarization. Conceivably, in diminishing transmitter release from presynaptic terminals the opioid peptides could have interfered with other presynaptic processes, e.g. calcium influx. The action potential of DR ganglionic cells was shortened in presence of $10^{-7} \mathrm{M} \mathrm{D}-\mathrm{Ala}^{2}$-ME-amide (Mudge et al., 1979a,b). Eliminating the $\mathrm{Na}^{+}$component in the inward currents with TTX did not abolish the peptide effect, thus indicating that the enkephalin analog diminished the $\mathrm{Ca}^{2+}$ inward current. The postsynaptic dendrite $\mathrm{Ca}^{2+}$ spike in hippocampal pyramidal cells was however not affected by enkephalins (Haas and Gähwiler, 1981).

Most of the intracellular recordings that could be obtained from neurons in the spinal cord and many other brain structures showed that the opioid peptides failed to alter the RMP and membrane resistance (MR). Thus, the cat DH cells and motoneurons exhibited no changes in RMP and MR following iontophoretic application of ME and LE (Zieglgänsberger and Tulloch, 1979a). Similar measurements remained unchanged during superfusion of rat and chicken embryos with $1-20 \mu \mathrm{M}$ concentrations of $\mathrm{ME}$, D-Ala ${ }^{2}$-D-Leu ${ }^{5}$-enkephalin of D-Ala ${ }^{2}-\mathrm{ME}$ amide (Mudge et al., 1979a; Williams and Zieglgänsberger, 1981). ME and LE never altered the RMP of the myenteric plexus neurons isolated from guinea-pig ileum when the peptides were applied iontophoretically in the vicinity of these neurons (North et al., 1979). The membrane potential, input resistance and spike threshold of the hippocampal pyramidal cells in slice preparations (Nicoll et al., 1980; Dingledine, 1981; Siggins and Zieglgänsberger, 1981) or maintained in tissue culture (Gähwiler, 1980) could not be changed by either iontophoretically released or superfused ME, LE, D-Ala ${ }^{2}$-D-Leu ${ }^{5}$-enkephalin, the enkephalin analogs FK 33-824, FW 34-569 or $\beta \mathrm{E}$.

The marked ineffectiveness of the opioid peptides on electrical properties of the resting cell membranes in CNS neurons does not fully justify the exclusion of these principles from the list of candidates for neurotransmitters. In cultures to fetal murine spinal cord cells Barker (Barker et al., 1978b, 1980) found several transmitter-like actions of ME and LE including a presumptive increase in $\mathrm{Cl}^{-}$conductance and rapidly desenzitizing excitation. In addition, the peptides altered the spike threshold of the neurons in the absence of, or independent of any other membrane effects. It could be argued that those actions of peptides were atypical, perhaps limited to the immature spinal cord neurons. However, North (North, 1979; North et al., 1979) observed repeatedly that guinea-pig myenteric plexus neurons were hyperpolarized when enkephalins were administered by superfusion. The naloxone reversible hyperpolarization of myenteric cells had never occurred following iontophoretic release of the peptides near the cell bodies. Considering the morphology of the plexus cells, North (1979) interpreted these findings as being the result of peptide action on cell processes remote from the cell bodies. Conceivably, alterations in the resting membrane potential or membrane conductance elicited in the cell processes are not always reflected in the intracellular measurements made at the soma membrane. An action remote from the cell body may perhaps explain the naloxone reversible hyperpolarization and increased membrane conductance that could be found in some but not all neurons of locus coeruleus slices following superfusion with $300 \mathrm{nM}$ concentrations of D-Ala ${ }^{2}-\mathrm{ME}$ or D-Ala ${ }^{2}$-D-Leu ${ }^{5}$-enkephalin (Pepper and Henderson, 1980). Thus, a transmitter-like action of opioid peptides on the postsynaptic membrane is quite possible, at least in some cases. In frog SG cells, ME and D-Ala ${ }^{2}-\mathrm{ME}$ increased the negativity of the potential recorded 
across the sucrose gap (Wouters and van den Bercken, 1979b, 1980). In presence of a synaptic activity blocking agent, a treatment-related increase in negativity would indicate hyperpolarization of the SG neurons. Synaptic activity in the ganglion was not abolished and thus some presynaptic mechanism in this effect of enkephalins cannot be excluded.

It has frequently been observed that the response of single neurons to iontophoretically applied L-glutamate or aspartate is considerably reduced in presence of opioid peptides. Such a naloxone reversible depression by opioids of amino acid-induced excitation was seen for example in spinal cord moto- and interneurons (Zieglgänsberger and Tulloch, 1979a,b), hippocampal pyramidal neurons (Segal, 1977) and in cortical neurons (Zieglgänsberger and Fry, 1976; Zieglgänsberger et al., 1976). It has been shown that the neuronal excitations elicited by L-glutamate were associated with depolarization (see e.g. Zieglgänsberger and Puil, 1973; Zieglgänsberger and Champagnat, 1979; Gähwiler, 1980; for review see Krnjewic, 1974) and with markedly enhanced conductance for the sodium ions (Zieglgänsberger and Puil, 1973). In contrast to voltage-dependent (depolarizationinduced) $\mathrm{Na}^{+}$conductance, the glutamate-induced increased permeability for sodium was not affected by TTX. It may therefore be assumed that as, e.g. in the case of acetylcholine at the muscle fiber end plate (Katz, 1966), the glutamate-induced drop in membrane resistance involves primarily activation of the receptor-coupled ionophores. It appeared from the analysis of the reciprocal membrane currents as a function of the glutamate pulse magnitude that LE altered neither the number of glutamate molecules involved in the postsynaptic response nor the affinity of the receptors for this amino acid (Barker et al., 1978a). As mentioned earlier, the opioid peptides had little effect on the resting neuronal membrane indicating that they themselves do not activate any specific-coupled ionic conductances. However, once $\mathrm{Na}^{+}$conductance had been activated by an appropriate agonist, the functioning of the receptor-coupled sodium channels presumably became different in presence of the peptide. The modulatory effect of opioid peptides upon receptor-coupled $\mathrm{Na}^{+}$conductance certainly deserves greater attention as it may turn out to be an important postsynaptic action of these peptides. Perhaps this or a similar mechanism may also be involved in the peptide-induced attenuation of the excitation elicited by acetylcholine (Davies and Dray, 1976) or by Substance P (Zieglgänsberger and Tulloch, 1979a).

\section{CONCLUding Remarks}

The electrophysiological experiments reviewed here provide convincing evidence that the peptides derived from pro-opiomelanocortin may act upon the brain and alter neuronal processes. The experiments thereby support the original hypothesis (de Wied, 1969) indicating the brain as a target for pituitary hormones and for the neuropeptides formed from these hormones. The actual role of these principles in the neurophysiology of the brain has however not been demonstrated by these experiments. Peptides released from the pituitary gland can reach their sites of actions within the brain by way of the general circulation, by retrograde blood flow through the hypophyseal portal system or by means of the cerebrospinal fluid (Oliver et al., 1977; Dorsa et al., 1979; Mezey et al., 1978; Raporot et al., 1980). It can therefore be reasoned that the peptides administered systematically or i.c.v. will be carried and distributed within the brain by the same mechanisms as the principles released from the pituitary. It became clear from several experiments that peptides given via these routes can alter ongoing neuronal activity in many parts of the brain. For example, the systemic or i.c.v. injection of $\mathrm{ACTH}_{4-10}$ and the closely related $\alpha-\mathrm{MSH}$ accelerated the hippocampal theta activity accompanying PS (Urban and de Wied, 1976), slowed down the same activity recorded during operant conditioning (Urban et al., 1974) and altered EEGs and ERs derived from different cortical areas in humans and animals (Sandman et al., 1971; Velasco et al., 1972; Braconier et al., 1979; Miller et al., 1981) Interestingly, $\mathrm{ACTH}_{4-10}$ did not elicit activity in single neurons (Gent and Normanton, 1980) just as it failed to induce hippocampal theta activity or any other pattern of EEG activity indicating the activation of a specific neuronal network. 
However, $\mathrm{ACTH}_{4-10}$ considerably changed the responsiveness of single neurons and neuronal networks when they had been activated by some kind of stimulus (Urban and de Wied, 1976, 1978; Wouters and van den Bercken, 1979a). These effects mostly became visible some $30 \mathrm{~min}$ following the administration of $\mathrm{ACTH}_{4-10}$, reached a maximum between 60-90 min and lasted for several hours thereafter. A gradual long-term alteration in input/relationship of neuronal networks was not an action unique to $\mathrm{ACTH}_{4-10}$. A number of structurally different peptides e.g. $\beta \mathrm{E}$ arginine ${ }^{8}$-vasoprossin, Des-glycinamide arginine ${ }^{8}$-vasopressin or oxytocin all exhibited this type of effect following systemic or i.c.v. administration (Urban and de Wied, 1975; Bohus et al., 1978; de Wied et al., 1978a; Urban and de Wied, 1978). Thus if the pituitary releases peptides that are predetermined to act within the brain, it presumably does so in order to exert this kind of modulatory action.

It has been proposed that the centrally acting peptides of pituitary origin stimulate the acquisition and maintenance of adaptive responses to novel situations (de Wied, 1978). Conceivably, there can be as many adaptive responses as novel situations. The organism has no way of anticipating which set(s) of neurons, brain structures and neuronal networks it will need to engage in order to elicit a response appropriate to the novel situation. The releasing peptides to the brain which themselves do not constitute any direct stimulus for brain neurons, but which temporarily alter the responsiveness of these neurons to stimuli impinging upon them, would certainly be an excellent mechanism for improving the function in any set(s) of neurons, structures and neuronal networks needed for elaborating a response adequate to the novelty. The hypophyseal pro-opiomelanocortin is a precursor of $\beta$-LPH, ACTH, $\alpha$-MSH, $\beta$-MSH, $\beta \mathrm{E}$ and many other peptides (for review see de Wied and Jolles, 1982). It is not yet known which of these peptides eventually enter the brain, and what amounts of the peptides need to be accumulated in this organ in order to perform some function. In addition, different kinds of neurons and transmitter systems may exhibit different sensitivities towards different peptides. Future experiments with the pituitary principles should therefore not only examine the action of different peptides on each electrophysiological parameter, but do so for each peptide at various doses (dose-response procedure).

In contrast to the pituitary peptides, the neuropeptides synthetized in neurons might act strictly locally and thus function as some kind of neurotransmitters. For many years it has been known that the neurohypophyseal hormones oxytocin (OX) and vasopressin (AVP) are synthestized in neurosecretory neurons of the paraventricular, supraoptic and suprachiasmatic nuclei and transported by axons to the posterior pituitary (for review see Bern, 1966; Bern and Knowles, 1966; Hayward, 1977). The release of OX and AVP from their pituitary terminals is initiated by an action potential sent down the axon by the neurosecretory cells themselves (Wakerly and Lincoln, 1973; Cross, 1974; Wakerly et al., 1978 ) and is also regulated by a depolarization-coupled, $\mathrm{Ca}^{2+}$-dependent mechanism (Dreifuss et al., 1971) as is e.g. the release of neurotransmitter acetylcholine (Katz, 1966). Not all fibers of the hypothalamic neurosecretory neurons follow the common final pathway to the posterior pituitary. Some turn and project to several extrahypothalamic structures, e.g. the lateral septum (Buijs, 1978; Sofroniew and Weidl, 1978; Buijs et al., 1980; Hoorneman and Buijs, 1982), forming synaptoid contacts with the LSC neuron (Buijs and Swaab, 1979). The microiontophoretically applied AVP and OX can act directly and excite the LS neurons (Joëls and Urban, 1982). If the action potentials invade and depolarize the LS neurosecretory terminals, this depolarization would presumably also be associated with the release of OX or AVP from these terminals (Buijs and van Heerikhuizen, 1982) and the released hormones could act in the same way as excitatory neurotransmitters. The mediobasal hypothalamic pro-opiomelanocortin of the $\beta \mathrm{E}$ system resembles in some aspects that of OX and AVP. Cell bodies synthetize a peptide, presumably pro-opiomelanocortin (Watson et al., 1978; Bloch, 1979; Bugnon et al., 1979; Sofroniew, 1979) and the fibers carry peptide material, presumably $\beta \mathrm{E}$, to terminals in septal preoptic, subthalamic, thalamic and midbrain areas (Bloom et al., 1978; Finley et al., 1980). The spinal cord and brain neurons respond readily to $\beta \mathrm{E}$ ejected with pressure or by microiontophoresis in the vicinity of these neurons (for references see Table 1). The 
neuronal responses to thus applied $\beta \mathrm{E}$ exhibit a short onset latency and stop shortly after the end of administration indicating the presence of mechanisms terminating the action of the peptide. There is in vitro evidence for membrane bound enzymes cleaving $\beta \mathrm{E}$ into $\gamma, \alpha$ and other shorter endorphins (Burbach et al.,1980). Those or similar enzymes could be part of a cellular 'machinery' metabolizing $\beta \mathrm{E}$ and thus terminating its action. If the pro-opiomelanocortin cells were capable of generating an action potential that is propagated along the fibers, depolarizing the terminal and releasing $\beta \mathrm{E}$ from this terminal they could use this peptide in the same way as other neurons use neurotransmitters.

However in vitro, pro-opiomelanocortin peptides, including the enkephalins, appeared quite ineffective to alter the resting membrane potential and membrane resistance as do classical neurotransmitters (Katz, 1966). Instead, in many preparations, the peptides interfered with presynaptic transmitter release and with postsynaptic responses to transynaptic and chemical stimuli. This action may represent a novel kind of interneuronal communication or a mechanism regulating the homeostasis of neuronal processes in discrete brain loci.

The cleavage products of $\beta$-endorphin, the $\gamma$ - and $\alpha$-type endorphins, are not biologically inert peptides. When given s.c. or i.c.v. they elicited distinctly different effects on behavioral (Bohus et al., 1978, 1980; de Wied et al., 1978a) and electrophysiological (Urban and de Wied, 1982) parameters. It was therefore suggested that the synaptically released $\beta \mathrm{E}$ is transformed into $\gamma$ - or $\alpha$-type endorphins each having a different function at the site where it is formed (de Wied and Jolles, 1982). The biotransformation of $\beta \mathrm{E}$ into $\gamma$ - and $\alpha$-endorphin presumably occurs in vivo as both types of endorphins were found in small but detectable amounts in extracts prepared from septum, thalamus and midbrain tissue (Verhoef et al., 1980, 1982). The endorphins recovered from the brain extracts could however have originated from the intrasynaptic compartment suggesting that enzymatic biotransformation of $\beta E$ could occur in the terminals prior to secretion. In such a case, the effective end product released from the terminal would not be $\beta \mathrm{E}$ but some other peptide. Practically nothing is known about the action of $\beta \mathrm{E}$ and its metabolites on neurons and neuronal processes in structures indicated by immunohistochemistry as being recipients of $\beta \mathrm{E}$ peptidergic innervation. Only future electrophysiological experiments could give us a better insight into the significance of pro-opiomelanocortin and other peptidergic systems within the brain.

Finally, some neuropeptides derived from pro-opiomelanocortin may turn out to be new agents suited for the treatment of mental disorders (de Wied and Van Ree, 1982). For example, behavioral and electrophysiological experiments indicated a mildly excitatory action of $\mathrm{ACTH}_{4-10}$ on the brain (see for review de Wied and Jolles, 1982 and also Sections 3.0 and 4.0 of this review). This property of the peptide could be applied e.g. to improve the brain function of elderly patients. In one clinical study, $\mathrm{ACTH}_{4-10}$ weakly improved attention in mentally retarded subjects, facilitated retrieval from memory and reduced depression and confusion in elderly patients (Braconnier et al., 1979). The orally acting $\mathrm{ACTH}_{4-9}$ (Greven and de Wied, 1977) (Org 2766) promoted friendliness, decreased unsociability, self-rated anxiety and depression and increased the self-rated competence in aged subjects (Pigache and Rigter, 1981). Another peptide, DT $\gamma$ E, temporarily ameliorated the psychotic symptoms in a group of patients for whom treatment with neuroleptics was indicated (Verhoeven et al., 1979). The neuroleptic-like activity of this peptide had been anticipated from the results of behavioral experiments utilizing avoidance procedures, various grip tests and self-stimulation (de Wied et al., 1978b, 1980; Dorsa et al., 1979b; van Ree and Otte, 1980). DT $\gamma \mathrm{E}$ differed from neuroleptics in some of its actions. The peptides did not displace $\left[{ }^{3} \mathrm{H}\right]$ spiperone, $\left[{ }^{3} \mathrm{H}\right]$ haloperidol and $\left[3^{3} \mathrm{H}\right]$ apomorphine from their specific binding to brain membrane preparations (Van Ree et al., 1978) and elicited in the lateral septum of rats EEG patterns that were different from those seen after haloperidol administration (Urban and de Wied, 1982). In addition, the $\gamma$-endorphins failed to decrease locomotor activity and elicited neither sedation nor any other symptom indicating an action on the extrapyramidal systems that is intrinsic to neuroleptic drugs. Thus, the behavioral, biochemical and electrophysiological experiments suggested that the beneficial 
therapeutic effects of neuroleptics presumably reside in actions other than those previously anticipated for agents of this group. The experiments also indicated that this kind of multidiciplinary effort is an efficient strategy for the development of new, more specific neurotropic drugs and an important approach that could provide new clues to the etiology of mental disorders.

\section{REFERENCES}

Allison, T., GoFf, W. R., Williamson, P. D. and VAN Gilder, J. C. (1974) On the neural origin of early components of the human somatosensory evoked potential. In: Proceedings of the International Symposium on Cerebral Evoked Potentials in Man, pp. 348-362, DeSMEDT, J. E. (ed.) Karger, Basel.

Andersen, R. K., Lund, J. P. and PuIL, E. (1978) Enkephalin and substance P effects related to trigeminal pain. Can. J. Physiol. Pharmac. 56: 216-222.

Angst, J., Autenrieth, V., Brem, F., Koukou, M., Meyer, H., Stassen, H. H. and Storck, U. (1979) Preliminary results of treatment with $\beta$-endorphin in depression. In: Endorphins in Mental Health Research, pp. 518-528, Usdin, E., Bunney, W. E., JR and Kline, N. (eds) Macmillan Press, London.

Arnolds, D. E. A. T., Lopes Da Silva, F. H., Aitkin, J. W. and Kamp, A. (1979a) Hippocampal EEG and behavior in dog. I. Hippocampal correlates of gross motor behaviour. Electroencephalogr. clin. Neurophysiol. 46: $552-570$.

Arnolds, D. E. A. T., Lopes Da Silva, F. H., Aitkin, J. W. and Kamp, A. (1979b) Hippocampal EEG and behaviour in dog. II. Hippocampal EEG correlates with elementary motor acts. Electraencephalogr. clin. Neurophysiol. 46: 571-580.

ATWEH, S. F. and KuHAR, M. J. (1977a) Autoradiographic localization of opiate receptor in rat brain. I. Spinal cord and lower medulla. Brain Res. 124: 53-67.

ATWEH, S. F. and KuHAR, M. J. (1977b) Autoradiographic localization of opiate receptors in rat brain. II. The brain stem. Brain Res. 129: 1-12.

AtWeh, S. F., MURrin, L. C. and KUhar, M. J. (1978) Presynaptic localization of opiate receptors in the vagal and accessory optic systems: an autoradiographic stage. Neuropharmacology 17: 65-71.

BALDWIN, D. M., HAUN, C. K. and SAWYER, C. H. (1974) Effects of intraventricular infusions of ACTH $\mathrm{AC}_{1-24}$ and $\mathrm{ACTH}_{4-10}$ on LH release, ovulation and behavior in the rabbit. Brain Res. 80: 291-301.

Barker, J. L., Grol, D. L., Huang, L. Y. M., MacDonald, J. F. and Smith, T. G. (1980) Peptides: pharmacological evidence for three forms of chemical excitability in cultures mouse spinal neurons. Neuropeptides 1: 63-82.

Barker, J. L., Neale, J. H., SMith, T. G. and MacDonald, R. L. (1978a) Opiate peptides modulation of amino acid response suggests several forms of neural communication. Science 199: 1451-1453.

Barker, J. L., Smith, T. G. and Neale, J. H. (1978b) Multiple membrane action of enkephalin revealed using cultured spinal neurons. Brain Res. 154: 153-158.

BERN, H. A. (1966) On the production of hormones by neurones and pole of neurosecretion in neuroendocrine mechanisms. Soc. exp. Biol. Symp. 20. (Nervous and Hormonal Mechanisms of Ingtegration).

Bern, H. A. and Knowles, F. G. W. (1964) Neurosecretion. In: Neuroendocrinology, pp. 139-180, vol. 1, Martini, L. and Ganong, W. F. (eds) Academic Press, New York.

BiCKELL, R. J. and LENG, G. (1982) Endogenous opiates regulate oxytocin but not vasopressin secretion from the neurohypophysis. Nature 298: 101-102.

Birnberger, K. L., Rüdel, R. and STRUPPleR, A. (1977) ACTH and neuromuscular transmission: Electrophysiological in vitro investigation of the effects of corticotropin and an ACTH fragment on neuromuscular transmission. Ann. Neurol. 1: 270-275.

BlaCK, A. H. (1976) Hippocampal electrical activity and behavior. In: The Hippocampus: A Comprehensive Treaties, pp. 129-168, IsaAcson, R. L. and Pribram, K. H. (eds) Plenum, New York.

Bloch, B., Bugnon, C., Fellman, D., LenYs, D. and Gouget, A. (1979) Neurons of the rat hypothalamus reactive with antisera against endorphins. ACTH, MSH and $\beta$-LPH. Cell Tissue Res. 204: 1-15.

BLoom, F. E. (1975) To spritz or not to spritz: the doubtful value of aimless iontophoresis. Life Sci. 14, 1819-1834.

BLOOM, F. E. (1981) Neuropeptides. Sci. Am. 245: 114-125.

Bloom, F. E., Battenberg, E., Rossier, J. Ling, N. and Guillemin, R. (1978) Neurons containing $\beta$-endorphin in rat brain exist separately from those containing enkephalins: immunocytochemical study. Proc. natn. Acad. Sci. U.S.A. 75: 1591-1595.

Bloom, F. E., Rossier, J., Battenderg, E. L. F., Bayon, A., French, E., Henriksen, S. J., Siggins, G. R., Ling, N. and GuILLEMIN, R. (1979) $\beta$-Endorphin: cellular localization, electrophysiological and behavioral effects. In: Endorphins in Mental Health Research, p. 17-29, UsDin, E., BunNEY, W. E. and KLEIN, N. S. (eds) Macmillan Press, London.

Bohus, B., Van Ree, J. M. and DE WIED, D. (1980) Psychostimulant-like behavioral activities of $\alpha$-endorphin and Des-Try'- $\alpha$-endorphin. Neurosci. Letters (suppl) 5: S352.

Bohus, B., Urban, I., van Wimersma Greidanus, Tj.B. and DE Wied, D. (1978) Opposite effects of oxytocin and vasopressin on avoidance behavior and hippocampal theta rhythm in rat. Neuropharmacology 17: 239-247.

BranConnier, R. J., COLE, J. O. and Gardon, G. (1979) ACTH $_{4-10}$ in the amelioration of neuropsychological symptomatology associated with senile organic brain syndrome. Psychopharmacology 61: 161-165.

Bradbury, A. F., Feldberg, W. F., Smyth, D. G. and Snell, C. R. (1976a) Lipotropin C-fragment: An endogenous peptide with potent analgesic activity. In: Opiates and Endogenous Opioid Peptides, pp. 9-17, Kosterlitz, H. W. (ed.) North-Holland, Amsterdam.

Bradbury, A. F., Smyth, D. G., Snell, C. R., Birdsall, N. J. M. and Hulme, E. C. (1976b) C-fragment of lipotropin has a high affinity for brain opiate receptors. Nature 260: 793-795. 
Bradley, P. B., Briggs, I., Gayton, R. J. and Lambert, L. A. (1976) Effect of microiontophoretically applied methionine-enkephalin on single neurons in rat brain stem. Nature 261: 425-426.

Bradley, P. B. and Bramwell, G. J. (1977) Stereospecific actions of morphine on single neurons in brain stem of the rat. J. Neuropharmac. 16: 519-526.

Bradley, P. B., Gayton, R. I. and Lambert, L. A. (1978a) Electrophysiological effects of opiates and opioid peptides. In: Centrally Acting Peptides, pp. 215-225, Hughes, J. (ed.) McMillan Press, London.

BradLey, P. B., Gayton, R. I. and LAMBERT, L. A. (1978a) Microiontophoretic study of opioid peptides on single neurons in the rat. In: Iontophoresis and Transmitter Mechanisms in the Mammalian Central Nervous System, pp. 305-307, Ryall, R. W. and Kelly, J. S. (eds) Elsevier, Amsterdam.

BuchWAld, J. S., Holstein, S. B. and Weber, D. S. (1973) Multiple unit recording: Technique, interpretation and experimental analysis. In: Bioelectric Recording Techniques, Part A, pp. 202-238, ThOMPson, R. F. and Patterson, H. M. (eds) Academic Press, New York/London.

Bugnon, C., Bloch, B., Lenys, D., Gouget, A. and Fellman, D. (1979) Comparative study of the neuronal population containing $\beta$-endorphin, corticotropin- and dopamine in the arcuate nucleus of the rat hypothalamus. Neurosci. Lett. 14: 43-48.

Buiss, R. M. (1978) Intra- and extrahypothalamic vasopressin and oxytocin pathways in the rat. Cell Tissue Res. 192: $423-435$.

Buiss, R. M. and SwaAB, D. F. (1979) Immunoelectron microscopic demonstration of vasopressin and oxytocin synapses in the limbic system of the rat. Cell Tissue Res. 204: 355-365.

BuiJs, R. M., Velis, D. N. and SwaAB, D. F. (1980) Extrahypothalamic vasopressin and oxytocin innervation of fetal and adult rat brain. Prog. Brain Res. 53: 159-167.

BuiJs, R. M. and VAN HeERIKHUIZE, J. J. (1982) Vasopressin and oxytocin release in the brain-a synaptic event. Brain Res. 202: 71-76.

Burbach, J. P. H., Loeber, J. G., Verhoef, J., Wiegant, V. M., De Kloet, E. R. and de Wied, D. (1980) Selective conversion of $\beta$-endorphin into peptides related to $\gamma$ - and $\alpha$-endorphin. Nature 28: 96-97.

BuRCH, N. R. (1959) Automatic analysis of the electroencephalogram. A review and classification of systems. Electroencephalogr. clin. Neurophysiol. 11: 827-834.

Burke R. E. and Rudomin, P. (1977) Spinal neurons and synapses. In: Handbook of Physiology: The Nervous System, vol. 1, Part 2, p. 877-944, GeIGER, S. R. (ed.) American Physiological Society, Bethesda, Maryland.

BYFoRD, G. H. (1965) Analysis of electroencephalogram. Mathematics and Computer Science in Biology and Medicine. Medical Research Council.

Calvillo, O., Henry, J. L. and Neuman, R. S. (1974) Effects of morphine and naloxon on dorsal horn neurons in the cat. Can. J. Physiol. Pharmac. 52: 1207-1211.

Carstens, E., Tulloch, I., Zieglgänsberger, W. and Zimmermann, M. (1979) Presynaptic excitability changes induced by morphine in single cutaneous afferent C- and A-fibers. Pfluegers Arch. 379: 143-147.

Chatrian, G. E., Bergamini, L., Dondey, M., Klass, D. W., Lennox-Butchtal, M. and Petersén, I. (1974) A glossary of terms most commonly used by clinical electroencephalographers. Electroencephalogr. clin. Neurophysiol. 37: 538-548.

Cross, B. A. (1974) The neurosecretory impulse. In: Neurosecretion-The Final Neuroendocrine Pathway, pp. 115-128, KnOwles, F. and Wollrath, L. (eds) Springer Verlag, Berlin.

Curtis, D. R. (1964) Microiontophoresis. In: Physical Techniques in Biological Research, Vol. V, pp. 144-192, NastuK, W. L. (ed.) Academic Press, New York.

Curtis, D. R., Duggan, A. W., Felix, D., Johnston, G. A. R., Tebecis, A. K. and Watkins, J. L. (1972) Excitations of mammalian central neurons by acidic amino acids. Brain Res. 41: 283-301.

Davies, J. and DraY, A. (1976a) Effects of enkephalin and morphine on Renshaw cells in feline spinal cord. Nature 262: 603-604.

Davies, J. and Dray, A. (1976a) Actions of enkephalin and morphine on spinal cord and brain stem neurones. Proc. Br. Pharmac. Sic. \& Ass. Francaise des Pharmacologistes, 15-17th September 1976, C65.

DaviEs, J. and Dray, A. (1978) Pharmacological and electrophysiological studies of morphine and enkephalin on rat supraspinal neurons and cat spinal neurons. Br. J. Pharmac. 63: 87-96.

DAviEs, J. and DraY, A. (1980) Depression and facilitation of synaptic responses in cat dorsal horn by substance $P$ into substantia gelatinosa. Life Sci. 27: 2037-2042.

Denavit-Saubié, M., Champagnat, J. and Zieglgänsberger, W. (1978) Effects of opiates and methioninenkephalin on pontine and bulbar respiratory neurones of the cat. Brain Res. 155: 55-67.

Denman, P. H., Miller, L. H., Sandman, C. A., Shally, A. V. and Kastin, A. J. (1972) Electrophysiologic correlaties of melanocyte-stimulating hormone activity in the frog. J. comp. Physiol. Psychol. 80: 59-65.

DE WIED, D. (1969) Effects of peptide hormones on behavior. In: Frontiers in Neuroendocrinology, pp. 97-140. GanONG, W. E. and Martin, L. (eds) Oxford University Press, London.

DE WIED, D. (1974) Pituitary-adrenal system hormones and behavior. In: The Neurosciences, Third Study Program, pp. 653-666, SCHMitT, F. O. and Worden, F. G. (eds) MIT Press, Cambridge.

DE WIED, D. (1979) Pituitary neuropeptides and behavior. In: Central Regulation of the Endocrine System. pp. 297-314, FuXe, K. HöKFelt, T. and Luft, R. (eds) Plenum, New York.

DE WIED, D., BohUs, B., VAN REE, J. M. and URBAN, I. (1978a) Behavioral and electrophysiological effects of peptides related to lipotropin ( $\beta$-LPH) J. Pharmac. exp. Ther. 204: 570-580.

DE Wied, D., Kovacs, G. L., Bohus, B., VAN Ree, J. M. and Greven, H. M. (1978b) Neuroleptic activity of the neuropeptide $\beta$-LPH 62-67 (Des-Tyr ${ }^{1}$ )- $\gamma$-endorphin. Eur. J. Pharmac. 49: 427-436.

DE WIED, D. and JolLes, J. (1982) Neuropeptides derived from pro-opiocortin: Behavioral, physiological and neurochemical effects. Physiol. Rev. 62: 976-1059.

DE Wied, D., VAN ReE, J. M. and Greven, H. M. (1980) Neuroleptic-like activity of peptides related to (Des-Tyr $\left.{ }^{1}\right)-\gamma$-endorphin: structure activity studies. Life Sci. 26: 1575-1579.

DE WIED, D. and VAN REE, J. M. (1982) Neuropeptides, mental performance and aging. Life Sci. 31: 709-719. Dingledine, R. (1981) Possible mechanisms of enkephalins action on hippocampal CAl pyramidal neurons. J. Neurosci. 1: 1022-1035. 
Donaldson, J., St. Pierre, T., Minnich, J. and Barbeau, A. (1971) Seizures in rats associated with divalent cation inhibition of $\mathrm{Na}^{+}-\mathrm{K}^{+}$ATPase. Can. J. Biochem. 49: 1217-1224.

Dorsa, D. M., De Kloet, E. R. Mezey, E. and DE Wied, D. (1979a) Pituitary-brain transport of neurotensin: functional significance of retrograde transport. Endocrinology 104: 1663-1666.

DoRsa, D. M., VAN REE, J. M. and DE WIED, D. (1979b) Effects of (Des-Tyr ${ }^{1}$ )- $\gamma$-endorphin and $\alpha$-endorphin on substantia nigra self-stimulation. Pharmac. Biochem. Behav. 10: 899-905.

Dreifuss, I. I., Kalnins, I., Kelly, J. S. and BUf, K. B. (1971) Action potentials and release of neurohypophyseal hormones in vitro. J. Physiol. (Lond.) 215: 805-817.

Drouva, S. V., Epelbaum, J., Tapia-Arancibia, L., Laplante, E. and Kordon, C. (1981) Opiate receptors modulate LHRH and SRIF release from mediobasal hypothalamic neurons. Neuroendocrinology 32: $163-167$.

Duggan, A. W., Hall, J. G. and Headley, P. M. (1976) Morphine, enkephalin and the substantia gelatinosa. Nature 264: 456-457.

Duggan, A. W., Hall, J. G. and Headley, P. M. (1977) Enkephalins and dorsal neurons of the cat: Effect on responses to noxious and innoxious skin stimuli. Br. J. Pharmac. 61: 399-408.

DuggaN, A. W. and HeadLey, P. M. (1978) The substantia gelatinosa and transmission of nociceptive impulses: Effects of morphine and methionine enkephalins amide. In: Iontophoresis and Transmitter Mechanisms in the Mammalian Central Nervous System, pp. 317-319, RYall, R. W. and Kelly, J. S. (eds) Elsevier, Amsterdam.

Dunwiddie, T., Meuller, A., Palmer, M., Stewart, J. AND Hoffer, B. (1980) Electrophysiological interactions of enkephalins with neuronal ciruitry in the rat hippocampus. I. Effects on pyramidal cell activity. Brain Res. 184: $311-330$.

Dupont, A., Lepine, J., Langelier, D., Herand, Y., Rokleau, D. Vaudry, H.,Gris, C. and Barden, N. (1980) Differential distribution of $\beta$-endorphin and enkephalins in rat and bovine brain. Reg. Peptides 1: $42-52$.

Dyster-AAs, H. K. and KRAKAU, C. E. T. (1965) General effects of $\alpha$-melanocyte stimulating hormone in the rabbit. Acta endocr. 48: 609-618.

EgAN, T. M. and NORTH, R. A. (1981) Both $\mu$ and $\delta$ opiate receptors exist on the same neuron. Science 214: 923-924.

Elazar, Z., Motles, E., Ely, Y. and Simantov, R. (1978) Acute tolerance to the excitatory effect of enkephalin microinjections into hippocampus. Life Sci. 24: 541-548.

Elde, R., Hökfelt, T., Johansson, O. and TeRenius, L. (1976) Immunohistochemical studies using antibodies to leucine-enkephalin; initial observation on the nervous system of the rat. Neuroscience 1: 349-351.

ENDRÖCZI, E., LISSAK, K., FEKETE, M. and DE WIED, D. (1970) Effects of ACTH on EEG habituation in human subjects. In: Pituitary, Adrenal and Brain, pp. 254-262, DE WIED, D and WeIJnen, J. A. W. M. (eds) Elsevier, Amsterdam.

FAIRCHILD, M. D., Jenden, D. J. and Mickey, M. R. (1971) Quantitative analysis of some drug effect on the EEG by long-term frequency analysis. Proc. west. Pharmac. Soc. 14: 135-140.

Fehm-Wolfsdorf, G., Elbert, T., Lutzenberger, W., Rockstroh, B., Birbaumer, N. and Fehm, H. L. (1981) Effect of an $\mathrm{ACTH}_{4-9}$ analog on human cortical evoked potentials in a two-stimulus reaction time paradigm. Psychoneuroendocrinology 6: 311-320.

Fields, H. L., Emson, P. C., Leigh, B. K., Gilbert, R. F. T. and Iversen, L. L. (1980) Multiple opiate receptor sites on primary afferent fibres. Nature 284: 351-353.

Fink, M. (1968) EEG classfication of psychoactive compounds in man: A review and theory of behavioral associations. In: Psychopharmacology: A Review of Progress 1957-1967, pp. 497-507, EfFron, D. H. (ed.) U.S. Public Health Service Publ. no. 1836.

FINK, M. (1974) EEG profiles and bioavailability measures of psychoactive drugs. In: Modern Drugs and the Human EEG. Karger, Basel.

Finley, G. W., Lindström, P. and Petrusz, P. (1981) Immunocytochemical localization of $\beta$-endorphin containing neurons in the rat brain. Neuroendocrinology 33: 28-42.

Firemark, H. M. and Weitzman, R. E. (1979) Effects of $\beta$-endorphin, morphine and naloxon on arginine vasopressin secretion and the electroencephalogram. Neuroscience 4: 1895-1902.

FREDERICKSON, R. C. A. (1977) Enkephalin pentapeptides-a review of current evidence for a physiological role in vertebrate neurotransmission. Life Sci. 21: 23-42.

Frederickson, R. C. A. and NoRRIS, F. H., (1976) Enkephalin-induced depression of single neurons in brain areas with opiate receptors. Science 194: 440-442.

Frederickson, R. C. A. and NorRIS, F. H. (1978) Enkephalins as inhibitory neurotransmitters modulating nociception. In: Iontophoresis and Transmitter Mechanisms in the Mammalian Central Nervous System, pp. 320-322, Ryall, R. W. and Kelly, J. S. (eds) Elsevier, Amsterdam.

FRENK, H. URCA, G. and LieBesKInd, J. C. (1978a) Eplileptic properties of leucine- and methionine-enkephalin: Comparison with morphine and reversibility of naloxone. Brain Res. 147: 327-337.

FrenK, H., MCCARTY, B. C. and Liebeskind, J. C. (1978b) Different brain areas mediate the analgesic and epileptic properties of enkephalin. Science 200: 335-337.

Fry, J. P., ZieglgänSBerger, W. and HERZ, A. (1978) Tachyphyllaxis to enkephalin-tolerance and dependence at the single neurone level? In: Iontophoresis and Transmitter Mechanisms in the Mammalian Central Nervous System, pp. 323-325, Ryall, R. W. and Kelly, J. S. (eds) Elsevier, Amsterdam.

Fry, J. P., Zieglgänsberger, W. and Herz, A. (1979) Specific versus nonspecific actions of opioids on hippocampal neurons in the rat brain. Brain Res. 163: 295-305.

GäHWILER, B. H. (1980) Excitatory action of opioid peptides and opiates on cultured hippocampal pyramidal cells. Brain Res. 194: 193-203.

GeNT, J. P. and WOLSTENCROFT, J. H. (1976a) Effects of methionine-enkephalin and leucine-enkephalin compared with those of morphine on brain stem neurons in cat. Nature 262: 426-427.

GENT, J. P. and WOLSTENCROFT, J. H. (1976b) Action of morphine, enkephalin and endorphin on single neurons 
in the brain stem, including the raphe and periquenductal gray of the cat. In: Opiates and Endogenous Opioid Peptides, pp. 217-224, Kosterlitz, H. W. (ed.) North-Holland, Amsterdam.

Gent, J. P., Smyth, D. G., Snell, C. R. and Wolstencroft, J. H. (1977) Effects of C-fragment on brain stem neurons in the cat. Br. J. Pharmac. 60: 272P.

Gent, J. P. and Normanton, J. R. (1980) Antagonism of the excitatory action of ACTH (1-24) by (D-Phe $\left.{ }^{7}\right)$ ACTH $(4-10)$ on single neurons in the rat medulla. Br. J. Pharmac. 70: 80P-81P.

Gestaut, H., Miribel, G. Favel, P. and Vigoroux, M. (1959) Effects cliniques et electroencéphalographiques de l'ACTH dans les differents types d'epilepsie. Soc. France Neurol. 101: 753-762.

Glaser, G. H. (1953) Psychotic reactions induced by corticotropin (ACTH) and cortisone. Psychosom. Med. 15: $280-291$.

Glaser, G. H., KornFeld, D. S. and KNIGHT, R. P. (1955) Intravenous hydrocortisone, corticotropin and electroencephalogram. Arch. Neurol. Psychiat. 72: 338-344.

Gogolák, G., Petsche, H., Sterc, J. and Stumph, C. H. (1967) Septum cell activity in the rabbit under reticular stimulation. Brain Res. 5: 508-510.

Gogolák, G., Stump, C. H., Petsche, H. and Sterc, J. (1968) The firing pattern of septal neurons and the form of the hippocampal theta wave. Brain Res. 7: 201-207.

Green, J. A. and Arduin, A. A. (1953) Hippocampal electrical activity in arousal. J. Neurophysiol. 17: 533-557.

Greven, H. M. and DE WIED, D. (1977) Influence of peptides structurally related to ACTH and MSH on active avoidance behavior in rats. A structure-activity relationship study. Front. Horm. Res. 4: $429-442$.

Guillemin, R., Vargo, T., Rossier, J., Minick, S., Ling, N., Rivier, C., Vale, W. and Bloom, F. (1978) $\beta$-Endorphin and adrenocorticotropin are secreted concomitantly of the pituitary gland. Science 197: $1367-1369$.

Guyenet, P. G. and Aghajanian, G. K. (1977) Excitation of neurons in the nucleus locus coeruleus by substance $\mathrm{P}$ and related peptides. Brain Res. 136: 178-184.

HAAS, H. L. and GäHWILER, B. H. (1980) Do enkephalins directly affect calciumspike in hippocampal pyramidal cells? Neurosci. Lett. 19: 89-92.

HALLER, J. (1979) Quantification of the psychotropic drug-induced changes in the feline EEG. Doctoral Dissertation, Basel.

Hayward, J. N. (1977) Functional and morphological aspects of hypothalamic neurons. Physiol. Rev. 57: $574-681$.

Henkin, R. I., Gilbert, D. L., Stillman, I. and Di Polo, R. (1973) Ineffectiveness of adrenocorticosteroids and adrenocorticotropin in altering $\mathrm{Na}-\mathrm{K}$ currents in squid giant axon. Experienta 29: 555-556.

Henriksen, S. J., Bloom, F. E., McCoy, F., Ling, N. and Guillemin, R. (1978) $\beta$-Endorphin induces nonconvulsive limbic seizures. Proc. natn. Acad. Sci. U.S.A. 75: 5221-5225.

Henry, J. L. (1978) Peptides and transmission in central nociceptive pathways. In: Iontophoresis and Transmitter Mechanisms in the Mammalian Central Nervous System, p. 110-112, RYALL, R. W. and KeLly, J. S. (eds) Elsevier, Amsterdam.

Henry, J. L. and Neuman, R. S. (1974) Morphine depression of dorsal neurones in cat. Proc. Can. Fed. Biol. Soc. 17: 158.

Hill, R. G. and Pepper, C. M. (1976) The effect of morphine and met-enkephalin on nociceptive neurons in the rat thalamus. Proc. Br. Pharmac. Soc. \& Ass. Francaise des Pharmacologists, pp. 56, C66, 15-17th September 1976.

Hill, R. G. and PePper, C. M. (1978a) The depression of thalamic nociceptive neurons by D-Ala ${ }^{2}-\mathrm{D}-\mathrm{Leu}^{5}$-Enkephalin. Eur. J. Pharmac. 47: 223-225.

HiLl, R. G. and PePper, C. M. (1978b) Studies on the pharmacology of nociceptive neurons in the rat thalamus. In: Iontophoresis and Transmitter Mechanisms in the Mammalian Central Nervous System, pp. 329-331, Ryall, R. W. and Kelly, J. S. (eds) Elsevier, Amsterdam.

Hill, R. G., PePPer, C. M. and Michell, J. E. (1976) Depression of nociceptive and other neurons in the brain by iontophoretically applied met-enkephalins. Nature 262: 604-606.

Hillyard, S. A., Hink, R. F., Schwent, V. L. and Picton, T. W. (1973) Electrical signs of selective attention in the human brain. Science 182: 171-180.

Hökfelt, T., Elde, R., Johansson, O., Terenius, L. and Stein, L. (1977a) The distribution of enkephalin-immunoreactive cell bodies in the rat central neurons system. Neurosci. Lett. 5: 25-31.

Hökfelt, T., Jundahl, A., Terenius, L., Elde, R. and Nilson, G. (1977b) Immunohistochemical analysis of peptide pathways possibly related to pain and analgesia: Enkephalin and Substance P. Proc. natn. Acad. Sci. U.S.A. 74: 3081-3085.

Hoorneman, E. M. D. and Buiss, R. M. (1982) Vasopressin fibres pathways in the rat brain following suprachiasmatic nucleus lesioning. Brain Res. 243: 235-241.

Hosford, D. A. and HaIGler, H. J. (1980) Morphine and Methionine-Enkephalin: Different effects on spontaneous and evoked neuronal firing in the mesencephalic reticular formation of the rat. J. Pharmac. exp. Ther. 213: $355-363$.

HugHES, J. (1975) Isolation of an endogenous compound from the brain with pharmacological properties similar to morphine. Brain Res. 38: 295-308.

Hughes, J., Smith, T. W., Kosterlitz, H. W., Fothegill, L. H., Morgan, B. A. and Morris, H. R. (1975) Identification of two related pentapeptides from the brain with potent opiate agonist activity. Nature 258: $577-579$.

ITIL, T. M. (1974) Quantitative pharmaco-electroencephalography. Use of computerized cerebral biopotentials in psychotorpic drug research. In: Modern Problems of Pharmacopsychiatry, Vol. 1: Psychotropic Drugs and the Human EEG, pp. 42-75, ITIL, T. M. (ed.) Karger, Basel.

IVERSEN, L. L., IVERSEN, S. D. and BLOOM, F. E. (1980) Opiate receptors influence vasopressin release from nerve terminals in rat neurohypophysis. Nature 284: 350-351. 
Izumi, K., Donaldson, J., Minnich, J. and Barbeau, A. (1973) Oubain-induced seizures in rat: Modification by melatonin and melanocyte-stimulating hormone, Can. J. Physiol. Pharmac. 51: 572-578.

Jessel, T. M. and IverSEN, L. L. (1977) Opiate analgesics inhibit substance P release from rat trigmental nucleus. Nature 268: $549-551$.

Jö̈LS, M. and URBAN, I. J. A. (1982) The effect of microiontophoretically applied vasopressin and oxytocin on single neurons on the dorsal hippocampus and system of the rat. Neurosci. Lett. 33: 79-84.

John, R. E. and Schwartz, E. L. (1978) The neurophysiology of information processing and cognition. Ann. Rev. Psychol. 29: 1-29.

JoY, R. M., HANCE, A. J. and KILlAM, F. K., JR (1971) Spectral analysis of long EEG samples for comparative purposes. Neuropharmacology 10: 471-478.

Kamp, A. Lopes da Silva, F. H. and Storm VAN LeEuwen, W. (1971) Hippocampal frequency shifts in different behavior situations. Brain Res. 31: 287-294.

Kastin, A. J., Miller, L. H., Gonzàles-Barcena, D., Hawley, W. D., Dyster-Aas, K., Schally, A. V., Velasco de Para, L. and Velasco, M. (1971) Psychophysiologic correlates of MSH activity in man. Physiol. Behav. 7: 893-896.

KaTZ, B. (1966) Nerve, Muscle and Synapse. McGrawn-Hill, New York.

KawAI, N. and NIWA, K. (1978) Hyperpolarization of the excitatory nerve terminals of inhibitory nerve stimulation in lobster. Brain Res. 137: 365-368.

Kawakami, M., Koshino, T. and HatTori, Y. (1966) Changes in the EEG of the hypothalamus and limbic system after administration of ACTH, SU 4885 and ACH in rabbits with special reference to neurohumoral feedback regulation of pituitary-adrenal system. Jap. J. Physiol. 16: 551-569.

KLEIN, R. (1970) The effects of ACTH and corticosteroids on epileptiform disorders. Prog. Brain Res. 32: 263-269.

KLEMM, W. R. (1970) Correlation of hippocampal theta rhythm, muscular activity and brain stem reticular formation activity. Commun. Behav. Biol. 5: 147-151.

KLEMM, W. R. (1971) EEG and multiple-unit activity in limbic and motor system during movement and immobility. Physiol. Behav. 7: 337-343.

KLEMM, W. R. (1972a) Effects of electrical stimulation of the brain stem reticular formation on hippocampal theta rhythm and muscle activity in unanesthetized, cervical- and midbrain-transected rats. Brain Res. 41: 331-344.

KLEMM, W. R. (1972b) Ascending and descending influences in the brain stem reticulum; A re-examination. Brain Res. 36: 444-452.

Klemm, W. R., Dreyfus, L. R., Forney, E. and Mayfield, M.A . (1977) Morphine-induced regional and dose-response difference in multiple-unit activity in rabbits. Neuropharmacology 16: 191-204.

KokeTsu, K. (1969) Cholinergic synaptic potentials and the underlying ionic mechanisms. Fedn Proc. 28: 101-112.

KORÁNYı, L. and ENDRöCZı, E. (1970) Influence of pituitary-adrenocortical hormones on thalamo-cortical and brain stem limbic circuits. In: Pituitary, Adrenal and the Brain, Vol. 32, p. 120-130, DE WIED, D and Weijnen, J. A. W. M. (eds) Prog. Brain Res., Elsevier, Amsterdam.

KORÁNYI, L., Beyer, C. and GUZMÁN-FloRes, C. (1971a) Multiple unit activity during habituation, sleep-wakefulness cycle and the effect of ACTH and corticosteroid treatment. Physiol. Behav. 7: 321-329.

KoráNYI, L., BEYER, C. and GUSMÁN-FLoRES, C. (1971b) Effect of ACTH and hydrocortisone on multiple unit activity in the forebrain and thalamus in response to reticular stimulation. Physiol. Behav. 7: 331-335.

Kosterlitz, H. W. and Hughes, J. (1975) Some thoughts on the significance of enkephalin, the endogenous ligand. Life Sci. 17: 91-96.

KovÁCS, G. L. and DE WIED, D. (1978) Effects of amphetamine and haloperidol on avoidance behavior and exploratory activity. Eur. J. Pharmac. 53: 103-107.

KREBS, E. and ROUBICEK, J. (1979) EEG and clinical profile of a synthetic analogue of methionine-enkephalinFK 33-824. Pharmakopsychiatr. 53: 86-93.

KrivoY, W. and Zimmerman, E. (1977) Action of $\beta$-melanocyte stimulating hormone ( $\beta$-MSH) or $\alpha$-montoneurons of cat spinal cord. Eur. J. Pharmac. 46: 315-322.

KRnJevic, K. (1974) Chemical nature of synaptic transmission in vertebrates. Physiol. Rev. 54: 418-541.

KÜNKEL, H. (1977) Historical review of principal methods EEG informatics. In: A Didactic Review of Methods and Applications of EEG Data Processing, pp. 9-25, RÉMOND, A. (ed.) Elsevier, Amsterdam.

La Bella, F., Havlicek, V., Pinsky, C. and Leybin, L. (1978) Opiate-like naloxon-reversible effects of aldosterone sulfate in rats. Can. J. Physiol. Pharmac. 56: 940-944.

LAmotTe, C., Pert, C. B. and SNYDER, S. H. (1976) Opiate receptor binding in primate spinal cord: Distribution and changes after dorsal root section. Brain Res. 112: 407-412.

LEE, M. K., DUNWIDDIE, T. and HofFer, B. (1980) Electrophysiological interactions of enkephalins with neuronal circuitry in the rat hippocampus. II. Effects on interneuron excitability. Brain Res. 184: 331-342.

LIBET, B., CHICHIBU, S. and TOSAKA, T. (1968) Slow synaptic responses and excitability in sympathetic ganglion of the bullfrog. J. Neurophysiol. 31: 388-395.

LIBET, B. and TOSAKA, T. (1970) Dopamine as a synaptic transmitter and modulator in sympathetic ganglion: A different mode of synaptic action. Proc. natn. Acad. Sci. U.S.A. 67: 667-673.

Linseman, M. A. and GruPp, L. A. (1980) Acute and chronic opiate effects on units and EEG of medial thalamus and hippocampus: A latency analysis. Psychopharmacology 71: 11-20.

Loeber, J. G., Verhoef, J., Burbach, J. P. H. and WitTER, A. (1979) Combination of high pressure liquid chromatography and radioimmunoassay is a powerful tool for the specific and quantitative determination of endorphins and related peptides. Biochem. Biophys. Res. Commun. 86: 1288-1295.

Loh, H. H., Brase, D. A., Sampath-Kanna, S. M., Way, E. L. and Li, C. H. (1976) $\beta$-Endorphin in vitro inhibition of striatal dopamine release. Nature 264: 567-568.

Lord, J. A. N., WATERfield, A. A., Hughes, J. and Kosterlitz, H. W. (1977) Endogenous opioid peptides: multiple agonists and receptors. Nature 267: 495-499. 
MacDonald, R. L. and Nelson, P. G. (1978) Specific opiate-induced depression of transmitter release from dorsal root ganglion cell in culture. Science 199: 1449-1450.

Mains, R., Eipper, B. A. and Ling, N. (1977) Common precursor to corticotropins and endorphins. Proc. natn. Acad. Sci. U.S.A. 74: 3014-3018.

Maru, E., TAKahashi, L. K. and Iwahara, S. (1979) Effects of median raphe nucleus lesions on hippocampal EEG in the freely moving rat. Brain Res. 163: 223-234.

MatejCEK, M. and Devos, J. E. (1976) Selected methods of quantitative EEG analysis and their applications in psychotropic drug research. In: Quantitative Analytic Studies in Epilepsy, pp. 183-205, Kellaway, P. and Petersén, I. (eds) Raven Press, New York.

MATOUSEK, M. (1973) Review of various methods of EEG analysis. In: Handbook of Electroencephalography and Clinical Neurophysiology Vol. 5, Part A Frequency and Correlation Analysis, pp. 5A-5-5A, MATOUSEK, M. (ed.)

MCAFEe, D. A. and Greengard, P. (1971) Adenosin 3', 5'-monophosphate, electrophysiological evidence for a role in synaptic transmission. Science, 178: $310-312$.

Muehlenthaler, M., Gähwiler, B. H. and Dreifuss, J. J. (1980) Enkephalin-induced inhibition of hypothalamic paraventricular neurons. Brain Res. 197: 264-268.

Mezey, E., Palkovits, M., DE Kloet, E. R., Verhoef, J. and DE WIED, D. (1978) Evidence for pituitary brain transport of a behaviorally potent ACTH analog. Life Sci. 22: 831-838.

Miletic, V. and Randic, M. (1982) Neonatal rat spinal cord slice preparation: Postsynaptic effects of neuropeptides on dorsal horn neurons. Devl Brain Res. 2: 432-438.

Miller, L. H., Kastin, A. J., Sandman, C. A., Fink, M. and Van Veen, W. J. (1974) Polypeptide influences on attention, memory and anxiety in man. Pharmac. Biochem. Behav. 2: 663-668.

Miller, L. H., HaRris, L. C., Kastin, A. J. and VAN Riezen, H. (1976) Neuroheptapeptide influence on attention and memory in man. Pharmac. Biochem. Behav. (suppl.) 5: 17-21.

Miller, L. H., Kastin, A. J., Hayes, M., Sterste, A., Garcia, J. and Coy, D. H. (1981) Inverse relationship between onset and duration of EEG effects of six peripherally administered peptides. Pharmac. Biochem. Behav. 15: 845-848.

Mudge, A. W., Leeman, S. E. and Fischbach, G. D. (1979a) Enkephalin inhibits release of substance P from sensory neurons in culture and decreases action potential duration. Proc. natn. Acad. Sci. U.S.A. 76: $526-530$.

Mudge, A. W., Leeman, S. E. and Fischbach, G. D. (1979b) Effect of enkephalin on sensory neurons in cell culture: Inhibition of substance $P$ release and reduction of inward calcium currents. In: Endorphin in Mental Health Research, pp. 344-351, Usdin, E., Bunney, W. E., JR and KLINE, N. S. (eds) Macmillan Press, London.

Muehlethaler, M., Gaehwiler, B. H. and Dreifuss, J. J. (1980) Enkephalin-induced inhibition of hypothalamic paraventricular neurons. Brain Res. 197: 264-268.

NÄÄTÄNEN, R. (1975) Selective attention and evoked potentials in human-a critical review. Biol. Psychol. 2: $237-307$.

Nakanishi, S., Inoue, A., Kita, T., Nakamura, M., Chang, A. C. Y., Cohen, S. N. and Numa, S. (1979) Nucleotide sequence of cloned cDNA for bovine corticotropin- $\beta$-lipotropin precursor. Nature 278: 423-427.

Nicoll, R. A., Siggins, G. R., LiNG, N., Bloom, F. E. and Gulllemin, R. (1977) Neuronal actions of endorphins and enkephalins among brain region: A comparative microiontophoretic study. Proc. natn. Acad. Sci. U.S.A. 74: $2584-2588$.

Nicoll, R. A., Alger, B. E. and JAHR, C. E. (1980) Enkephalin blocks inhibitory pathways in the vertebrate CNS. Nature 287: 22-25.

Nishi, S. (1974) Ganglionic transmission. In: Peripheral Nervous System, pp. 225-255, Hubbard, J. I. (ed.) Plenum Press, New York.

NisHI, S. and KOKETSU, K. (1968) Analysis of slow inhibitory postsynaptic potentials of bullfrog sympathetic ganglion. J. Neurophysiol. 31: 717-728.

NORTH, R. A. (1979) Opiates, opiod peptides and single neurons. Life Sci. 24: 1527-1545.

North, R. A., Katayama, Y. and Williams, J. T. (1979) On mechanism and site of action of enkephalin on single myenteric neurons. Brain Res. 165: 67-77.

Oliver, C., Mical, R. S. and Porter, J. C. (1977) Hypothalamic-pituitary vasculature: Evidence for retrograde blood flow in the pituitary. Endocrinology 101: 598-604.

Orth, D. N. and Nickolson, W. E. (1977) Different molecular forms of ACTH. Ann. N. Y. Acad. Sci. 297: $27-46$

Paiva, T., Lopes Da Silva, F. H. and Mollenvanger, W. (1976) Modulating system of hippocampal EEG. Electroencephalogr. clin. Neurophysiol. 40: 470-480.

Palmer, M. R., Morris, D. H., TAYlor, D. A., Stewart, J. M. and Hoffer, B. J. (1978) Electrophysiological effects of enkephalin analogs in rat cortex. Life Sci. 23: 851-860.

Pepper, C. M. and Henderson, G. (1980) Opiates and opioid peptides hyperpolarize locus coeruleus neurons in vitro. Science 209: 395-396.

PerT, L. B., Kuhar, M. J. and SNYDER, S. H. (1975) Autoradiographic localization of the opiate receptor in rat brain. Life Sci. 16: 1849-1854.

Petsche, H., Stumph, C. H. and Gogolak, G. (1962) The significance of the rabbit septum as a relay station between the midbrain and hippocampus. I: The control of hippocampal arousal activity of septum cells. Electroencephalogr. clin. Neurophysiol. 14: 201-211.

Pfaff, D. W., SILVA, M. T. A. and Weiss, J. M. (1971) Telemetered recording of hormone effects on hippocampal neurons. Science 172: 394-395.

Pigache, R. M. and Rigter, L. (1981) Effects of peptides related to ACTH on mood and vigilance in man. Front. Horm. Res. 8: 193-207.

Pittman, Q. J., Hatton, J. D. and Bloom, F. E. (1980) Morphine and opioid peptides reduce paraventricular neuronal activity: Studies on the rat hypothalamic slice preparation. Proc. natn. Acad. Sci. U.S.A. 77: $5527-5533$. 
Pomeranz, B. and Gurevich, N. (1979) Effects of enkephalin analog and naloxon on cat spinal cord dorsal root potentials. Eur. J. Pharmac. 60: 307-313.

Randic, M. and Miletic, V. (1978) Action of peptides on cat dorsal neurons activated by noxious stimuli. In: Iontophoresis and Transmitter Mechanisms in the Mammalian Central Nervous System, pp. 124-126, RYALL, R. W. and KelLY, J. S. (eds) Elsevier, Amsterdam.

Raporot, S. J., Klee, W. A., Petigrew, K. D. and Ohno, K. (1980) Entry of opioid peptides into the central nervous system. Science 207: 84-86.

VAN ReE, J. M., WitTER, A. and LeIJSEN, J. E. (1978) Interaction of destyrosine- $\gamma$-endorphin(DT $\gamma$ E; $\beta$-LPH 62-77) with neuroleptic sites in various areas of the rat brain. Eur. J. Pharmac. 52: 411-413.

VAN REE, J. M. and OTTE, A. P. (1980) Effects of (Des-Tyr $\left.{ }^{1}\right)-\gamma$-endorphin and $\alpha$-endorphin as compared to haloperidol and amphetamine on nucleus accumbens self-stimulation. Neuropharmacology 29: 429434.

Rockstroh, B., Elbert, T., Lutzen, W., Birbaumer, N., Fehm, H. L. and Voigt, K. H. (1981) Effect of an $\mathrm{ACTH}_{4-9}$ analog on human cortical evoked potentials in a constant foreperiod reaction time paradigm. Psychoneuroendocrinology 6: 301-310.

SaLETU, B. (1974) Classification of psychotropic drugs based on human evoked potentials. In: Modern Problems in Pharmacopsychiatry, Vol. 8: Psychotropic Drugs and the Human EEG pp. 258-285, ITIL, T. M. (ed.) Karger, Basel.

Sandman, C. A., Denman, P. H., Miller, L. H., Knott, J. H., Schally, A. V. and Kastin, A. J. (1971) Electroencephalographic measures of melanocyte-stimulating hormone activity. J. comp. Physiol. 103: 103-109.

SANdman, C. A. and Kastin, A. J. (1981) The influence of fragments of the LPH chain on learning, memory and attention in animals and man. Pharmac. Ther. 13: 39-60.

SASTRY, B. R. (1978) Morphine and met-enkephalin effects on sural A $\delta$ afferent terminal excitability. Eur. $J$. Pharmac. 50: 269-273.

SATTERFIELD, J. H. (1965) Evoked cortical response enhancement and attention in man. A study of responses to auditory and shock stimuli. Electroencephalogr. clin. Neurophysiol. 19: 470-475.

Sawyer, C. H., Kawakami, M., Meyerson, B., Whitmoyer, D. J. and Lilley, J. J. (1968) Effects of ACTH, dexamethasone and asphyxia on electrical activity of the rat hypothalamus. Brain Res. 10: 213-226.

SCHALLEK, W. and KeUHN, A. (1959) Effects of drugs on spontaneous and activated EEG of cat. Arch. int. Pharmac. 120: 319-333.

SChallek, W., Lewinson, T. and Thomas, J. (1967) Power spectrum analysis of drug effects on electroencephalogram of cat. Int. J. Neuropharmac. 6: 253-264.

SChmidt, R. P. and Wilder, R. J. (1968) Epilepsy. F. A. Davis, Philadelphia.

SCHMIDT, R. F. (1971) Presynaptic inhibition in the vertebrate central nervous system. In: Reviews of Physiology, Biochemistry and Experimental Pharmacology, Vol. 63, pp. 20-101, Springer Verlag, Berlin.

SEGAL, M. (1976) Interaction of ACTH and norepinephrine on the activity of rat hippocampal cells. Neuropharmacology 15: 329-333.

Segal, M. (1977) Morphine and enkephalin interactions with putative neurotrasmitters in rat hippocampus. Neuropharmacology 16: 587-592.

SHAGASS, C. (1977) EEG and evoked potential approaches to the study of neuropeptides. In: Neuropeptide Influences on the Brain and Behavior, p. 29-60, Miller, L. H., Sandman, C. A. and Kastin, A. J. (eds) Raven Press, New York.

Siggins, G. R., Zieglgänsberger, W., French, E., Ling, M. and Bloom, F. E. (1978) Opiates and opioid peptides may excite hippocampal neurons by inhibiting adjacent inhibitory interneurons. Neurosci. Abstr. 4: 414 .

Siggins, G. R., Nicoll, R., Bloom F. E. and Ling, M. (1978) Regional actions of endorphins, enkephalins and normorphine in rat brain. In: Iontophoresis and Transmitter Mechanisms in the Mammalian Central Nervous System, pp. 338-341, RYall, R. W. and Kelly, J. S. (eds) Elsevier, Amsterdam.

SigGiNS, G. R. and ZIEGLGÄNSBERGER, W. (1981) Morphine and opioid peptides reduce inhibitory synaptic potentials in hippocampal pyramidal cells in vitro without alteration of membrane potential. Proc. natn. Acad. Sci. 78: 5235-5239.

SNyder, S. and Simantov, R. (1977) The opiate receptor and opioid peptides. J. Neurochem. 28: 12-30.

SofroniEw, M. V. (1979) Immunoreactive $\beta$-endorphin and ACTH in the same neurons of the hypothalamic arcuate nucleus in the rat. Am. J. Anat. 154: 283-289.

Sofroniew, M. V. and WEINDL. A. (1978) Extrahypothalamic neurophysin containing perikarya, fibers and fiber clusters in the rat brain. Endocrinology 102: 334-337.

STEINER, F. A. (1970) Effects of ACTH and corticosteroids on single neurons in the hypothalamus. In: Pituitary, Adrenal and the Brain, 102-107, DE WIED, D and WEIJEN, J. A. W. M. (eds) Elsevier, Amsterdam.

STORM VAN LeEUWEN, W. (1964) Complementarity of different analysis methods. Electroencephalogr. clin. Neurophysiol. 16: 136-139.

Storm van Leeuwen, W., Bickford, R. Brazier, M., Cobb, W. A., Dondey, M., Getaut, H., Gloor, P., Henry, C. E., Hess, R., Knott, J. R., Kugler, J., lairy, C., Loeb, C., Magnus, O., Oller Duarella, P., Petsche, H., Schwab, R., Walter, W. G. and WidÉn, L. (1966) Proposal for an EEG terminology by the terminology committee of the international federation for electroencephalography and clinical neurophysiology. Electroencephalogr. clin. Neurophysiol. 20: 293-320.

Strand, F. L. and CAYER, A. (1975) A modulatory of pituitary polypeptides on peripheral nerve and muscle Brain Res. 42: 187-194.

Strand, F. L. and Smith, C. M. (1980) LPH, ACTH, MSH and motor system. Pharmac. Ther. 11: 509-533.

Strand, F. L., Stoboy, H. and Cayer, A. A. (1973) A possible direct action of ACTH on nerve and muscle. Neuroendocrinology 13: 1-20.

Subramanian, N., Mitznegg, P., Sprügel, W., Domschke, S., Wünsch, E. and Demling, L. (1977) Influences 
of enkephalin on $\mathrm{K}^{+}$-evoked efflux of putative neurotransmitters in rat brain. Naunyn Schmiedebergs Arch. Pharmac. 299: 163-165.

Suze, T. and Jessell, T. (1980) Opiate analgesics and endorphins inhibit rat dorsal root potential in vivo. Neurosci. Lett. 16: 161-166.

TAylor, D., Hoffer, B., Zieglgänsberger, W., Siggins, G., Ling, N., Seiger, A. and Olson, L. (1979) Opiod peptides excite pyramidal neurons and evoke epileptiform activity in hippocampal transplants in oculo. Brain Res. 176: $135-142$.

ToRDA, C. and WolfF, H. G. (1952a) Effects of various concentration of adrenocorticotropic hormone on electrical activity of brain and on sensitivity to convulsion-inducing agents. Am. J. Physiol. 168: 906-913.

TORDA, C. and WolfF, H. G. (1952b) Effect of pituitary hormones, cortisone and adrenalectomy of some aspects of neuromuscular function and acetylcholine synthesis. Am. J. Physiol. 169: 140-149.

Tortella, F. C., Moreton, J. E. and Kazan, N. (1978) Electroencephalographic and behavioural effects of D-Ala ${ }^{2}$-methionine-enkephalin amide and morphine in the rat. J. Pharmac. exp. Ther. 206: 636-642.

URBAN, I. J. A. (1981) Intraseptal administration of vasopressin and oxytocin affects hippocampal electroencephalogram in rats. Expl Neurol. 74: 131-147.

Urban, I., Lopes Da Silva, F. H., Storm van Leeuwen, W. and de Wied, D. (1974) A frequency shift in the hippocampal theta activity: An electrical correlate of central action of ACTH analogues in dog. Brain Res. 69: $361-365$.

URBAN, I. and DE WIED, D. (1975) Inferior quality of RSA during paradoxical sleep in rats with hereditary diabetes insipidus. Brain Res. 97: 362-366.

URBAN, I. and DE WIED, D. (1976) Changes in excitability of the theta activity generating substrate by $\mathrm{ACTH}_{4-10}$ in the rat. Expl. Brain Res. 24: 325-334.

Urban, I. and DE WIED, D. (1978) Neuropeptides effect on paradoxical sleep and theta-rhythm in rats. Pharmac. Biochem. Behav. 8: 51-59.

URBAN, I. and DE WIED, D. (1978) Neuropeptides effect on paradoxical sleep and theta-rhythm in rats. Pharmac. Biochem. Behav. 8: 51-59.

URBAN, I. J. A. and DE WIED, D. (1982) Electroencephalographic changes in the lateral system complex following systemic administration of Des-Tyr ${ }^{1}-\alpha$-endorphin, Des-Tyr ${ }^{1}-\gamma$-endorphin and haloperidol in rats. Life Sci. 31: $2417-2424$

UrCA, G., Frenk, H., Liebeskind, J. C. and Taylor, A. H. (1977) Morphine and enkephalin analgesis and epileptic properties. Science 197: 83-86.

Valero, I., Stewart, J., McNaughton, N. and Gray, J. A. (1977) Septal driving of the hippocampal theta rhythm as a function of frequency in the male rat: effect of adrenopituitary hormones. Neuroscience 2: 1029-1032.

VAN DelfT, A. M. L. and KitaY, J. I. (1972) Effect of ACTH on single unit activity in the diencephalon of intact and hypophysectomized rats. Neuroendocrinology 9: 188-196.

VelasCo, M., WeINBERGER, N. M. and Lindley, D. B. (1968) Effect of thalamocortical activation on recruiting response. I. Reticular stimulation. Acta neurol. lat. am. 14: 99-115.

Velasco, M., Kastin, A. J. and Gonzáles BárCEnA, D. (1972) Effect of melanocyte-stimulating hormone on the cortical somatic evoked responses in man. Neuropharmacology 11: 395-407.

Verhoef, J., Loeber, J. G., Burbach, J. P. H., Gispen, W. H., WitTer, A. and DE WIED, D. (1980) $\alpha$-Endorphin, $\gamma$-endorphin and their Des-tyrosine fragments in rat pituitary and brain tissues. Life Sci. 26: 851-859.

VERHOEF, J., WIEGANT, V. M. and DE WIED, D. (1982) $\alpha$-Endorphin, $\gamma$-endorphin and their Des-Tyrosine fragments: Distribution in rat brain. In: Regulatory Peptides: From Molecular Biology to Function, pp. 69-74, Costa, E. and Trabucchi, M. (eds) Raven Press, New York.

Verhoeven, W. M. A., Praag, H. M. van and de Wied, D. (1979) Improvement of schizophrenic patients treated with (Des-Tyr')- $\gamma$-endorphin (DT $\gamma$ E). Arch. gen. Psychiatr. 36: 294-298.

VERSTEEG, D. H. G. (1980) Interaction of peptides related to ACTH, MSH and $\beta$-LPH with neurotransmitter in the brain. Pharmac. Ther. 11: 535-575.

Von Graffenried, B. V., Pozo, E. Del, Roubicek, J., Krebs, E., Pöldinger, W. Burmeister, P. and KreP, L. (1978) Effects of the synthetic analogue FK 33-824 in man. Nature 272: 729-730.

WAKERLEY, J. B. and LiNCOLN, D. W. (1973) The milk-ejection reflex of the rat: a 20 to 40 -fold acceleration in the firing of the paraventricular neurons during oxytocin release. $J$. Endocr. 57: 477-493.

Wakerley, J. B., Poulain, D. A. and Brown, D. (1978) Comparison of firing patterns in oxytocin- and vasopressin-releasing neurons during progressive dehydration. Brain Res. 148: 425-440.

Wallis, D. I., LeEs, G. H. and Kosterlitz, H. W. (1975) Recording resting and action potentials by sucrose gap method. Comp. Biochem. Physiol. 50: 199-206.

Wasserman, M. J., Belton, N. R. and Milichap, J. G. (1965) Effect of corticotropin (ACTH) on experimental seizures. Neurology 15: 1136-1141.

Waterfield, A. A. and Kosterlitz, H. W. (1975) Stereospecific increase by narcotic antagonists of evoked acetylcholine output in guinea-pig ileum. Life Sci. 16: 1787-1792.

Waterfield, A. A., Smokcum, R. W. J., Hughes, J., Kosterlitz, H. W. and Henderson, G. (1977) In vitro pharmacology of the opioid peptides enkephalins and endorphins. Eur. J. Pharmac. 43: 107-116.

Watson, S. J., Akil, H., Richard, C. W. III and BarChas, J. D. (1978) Evidence for two separate opiate peptide neuronal systems. Nature 275: 226-228.

Weight, F. F. (1974) Physiological mechanisms of synaptic modulation, In: The Neurosciences: Third Study Program, pp. 929-941, SchmiTt, F. O. and Worden, F. G. (eds) MIT Press, Cambridge.

Weight, F. F. and Padjen, A. (1973) Acetylcholine and slow synaptic inhibition in frog sympathetic ganglion cells. Brain Res. 55: 225-228.

Whishaw, I. Q. and VANDER WOLF, C. H. (1973) Hippocampal EEG and behavior. Changes in amplitude and frequency of RSA (theta rhythm) associated with spontaneous and learned movement patterns in rats and cats. Behav. Biol. 8: 461-484. 
Williams, J. and ZieglgäNSBERger, W. (1981) Mature spinal ganglion cells are not sensitive to opiate receptor mediated actions. Neurosci. Lett. 21: 211-216.

Wolstencroft, J. H., West, D. C. and Gent, J. P. (1978) Action of morphine and opioid peptides on neurons in the reticular formation, raphe nuclei and the periaqueductal gray. In: Iontophoresis and Transmitter Mechanisms in the Mammalian Central Nervous System, pp. 341-343, Ryall R. W. and Kelty, J. S. (eds) Elsevier, Amsterdam.

Wolthuis, O. L. and DE WIED, D. (1976) The effect of ACTH-analogues on motor behavior and visual evoked responses in rats. Pharmac. Biochem. Behav. 4: 273-278.

WOODBuRy, D. M. (1958) Relation between the adrenal cortex and the central nervous system. Pharmac. Rev. 10: $276-336$

WOUTERS, W. and VAN DEN BERCKEN, J. (1979a) Effects of ACTH 4-10 on synaptic transmission in frog sympathetic ganglion. Eur. J. Pharmac. 57: 353-366.

WOUTERS, W. and VAN DEN BERCKEN, J. (1979b) Hyperpolarisation and depression of slow synaptic inhibition by enkephalin in frog sympathetic ganglion. Nature 277: 53-54.

Wouters, W., ERmes-Busio, M. C. E. and Van DEN BerCKen, J. (1979c) ACTH $_{4-10}$ and neuromuscular transmission in rat diaphragme. An electrophysiollogical investigation into the action of some neuropeptides on synaptic transmission. Thesis, University of Utrecht.

WOUTERS, W. and VAN DEN BERCKEN, J. (1980) Effects of met-enkephalin on slow synaptic inhibition in frog sympathetic ganglion. Neuropharmacology 19: 237-243.

Yamamoto, T., Watanabe, S., OIShI, R. and UeKI, S. (1979) Effects of midbrain raphé stimulation and lesion on EEG activity in rats. Brain Res. Bull. 4: 491-495.

YounG, W. S., STEPHANIE, J. B. and KUHAR, M. J. (1977) Iontophoresis of methionine-enkephalin in the locus coeruleus area. Brain Res. 129: 366-370.

ZieglgäNSBERGER, W. (1980) An enkephalinergic gating system involved in nociception, In: Neural Peptides and Neuronal Communication pp. 425-434, Costa, E. and Trabucchi, M. (eds) Raven Press, New York.

Zieglgänsberger, W. and PUIL, E. A. (1973) Action of glutamic acid on spinal neurons. Expl. Brain Res. 17: $35-49$.

ZiEglgäNSBERgER, W. and FRY, J. P. (1976a) Action of enkephalin on cortical and striatal neurons of naive and morphine tolerant/dependent rats. In: Opiates and Endogenous Opioid Peptides, pp. 213-238, KosterLITZ, H. W. (ed.) North-Holland, Amsterdam.

ZIEGLGÄNSBERGER, W. and BAYERL, H. (1976b) The mechanism of inhibition of neuronal activity of opiates in the spinal cord of cat. Brain Res. 115: 111-128.

ZieglgänSBerger, W., Fry, J. P., Herz, A., Moroder, L. and Wünsch, E. (1976) Enkephalin-induced inhibition of cortical neurons and lack of this effect in morphine tolerant/dependent rats. Brain Res. 115: 160-164.

Zieglgänsberger, W. and FrY, J. P. (1978) Action of opioids on single neurons. In: Developmental Opiate Research, pp. 193-226, HERZ, A. (ed.) Dekker, New York.

Zieglgänsberger, W. and Champagnat, J. (1979) Cat spinal motoneurons exhibit topographic sensitivity to glutamate and glycine. Brain Res. 160: 95-104.

ZieglgäNSBERGER, W. and TULLOCH, I. F. (1979a) The effects of methionine- and leucine-enkephalin on spinal neurons of the cat. Brain Res. 167: 53-64.

ZieglgäNSBERger, W. and TUlloch, I. F. (1979b) Action of opiate agonists and substance P on dorsal horn neurons of the cat. In: Endorphins in Mental Research, pp. 293-201, UsDIN, E., BUNNEY, W. E., JR and KLEIN, N. S. (eds) Macmillan, London.

Zigglgänsberger, W., French, E. D., Siggins, G. R. and Bloom, F. E. (1979) Opioid peptides may excite hippocampal pyramidal neurons by inhibiting ajacent interneurons. Science 205: 415-417. 